\title{
Small, Modular Advanced High- Temperature Reactor-Carbonate Thermochemical Cycle
}

\section{March 2014}

\author{
Prepared by \\ D. E. Holcomb \\ D. Ilas \\ B. Middleton, SNL \\ M. Arrieta, SNL
}

Approved for public release; distribution is unlimited.

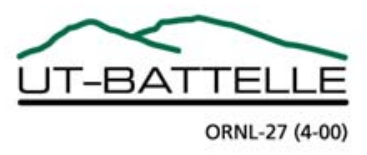




\section{DOCUMENT AVAILABILITY}

Reports produced after January 1, 1996, are generally available free via US Department of Energy (DOE) SciTech Connect.

Website http://www.osti.gov/scitech/

Reports produced before January 1, 1996, may be purchased by members of the public from the following source:

National Technical Information Service

5285 Port Royal Road

Springfield, VA 22161

Telephone 703-605-6000 (1-800-553-6847)

TDD 703-487-4639

Fax 703-605-6900

E-mail info@ntis.gov

Website http://www.ntis.gov/support/ordernowabout.htm

Reports are available to DOE employees, DOE contractors, Energy Technology Data Exchange representatives, and International Nuclear Information System representatives from the following source:

Office of Scientific and Technical Information

PO Box 62

Oak Ridge, TN 37831

Telephone 865-576-8401

Fax 865-576-5728

E-mail reports@osti.gov

Website http://www.osti.gov/contact.html

This report was prepared as an account of work sponsored by an agency of the United States Government. Neither the United States Government nor any agency thereof, nor any of their employees, makes any warranty, express or implied, or assumes any legal liability or responsibility for the accuracy, completeness, or usefulness of any information, apparatus, product, or process disclosed, or represents that its use would not infringe privately owned rights. Reference herein to any specific commercial product, process, or service by trade name, trademark, manufacturer, or otherwise, does not necessarily constitute or imply its endorsement, recommendation, or favoring by the United States Government or any agency thereof. The views and opinions of authors expressed herein do not necessarily state or reflect those of the United States Government or any agency thereof. 


\title{
SMALL, MODULAR ADVANCED HIGH-TEMPERATURE REACTOR- CARBONATE THERMOCHEMICAL CYCLE
}

\author{
D. E. Holcomb \\ D. Ilas \\ Oak Ridge National Laboratory \\ B. Middleton \\ M. Arrieta \\ Sandia National Laboratories
}

March 2014

\author{
Prepared by \\ OAK RIDGE NATIONAL LABORATORY \\ Oak Ridge, Tennessee 37831-6165 \\ managed by \\ UT-BATTELLE, LLC \\ for the \\ US DEPARTMENT OF ENERGY \\ under contract DE-AC05-00OR22725
}





\section{CONTENTS}

Page

LIST OF TABLE AND FIGURES

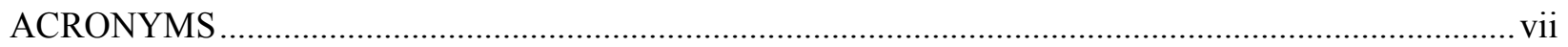

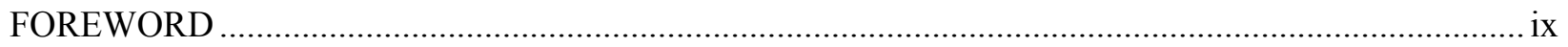

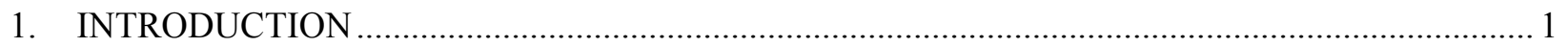

2. GENERAL DESCRIPTION OF THE PLANT CONFIGURATION ….................................... 2

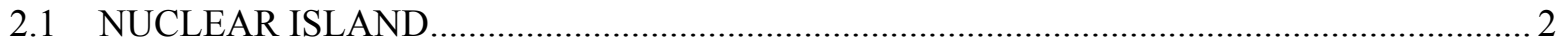

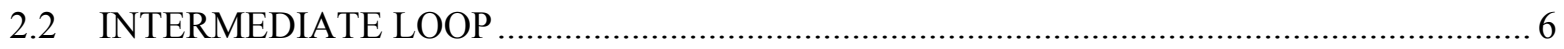

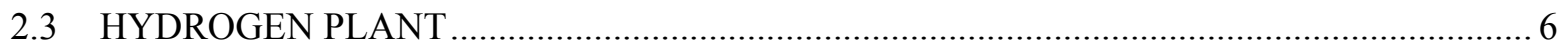

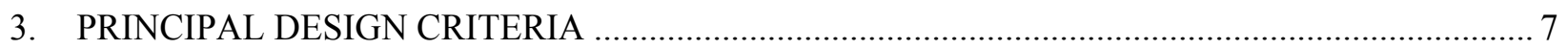

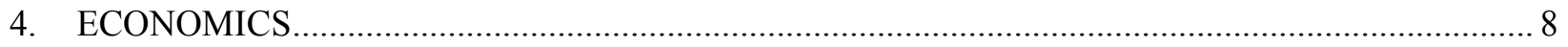

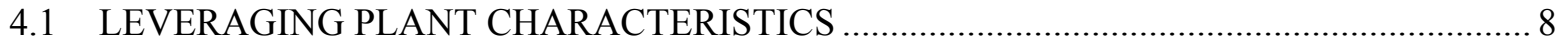

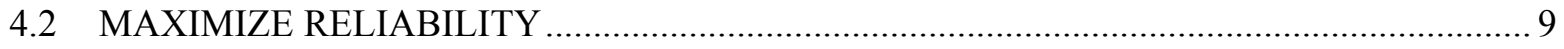

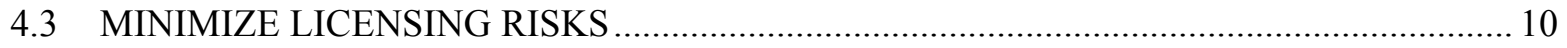

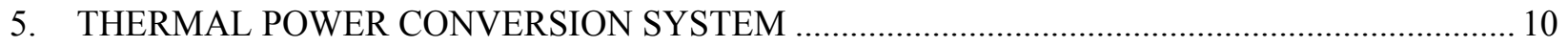

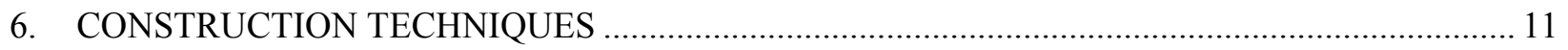

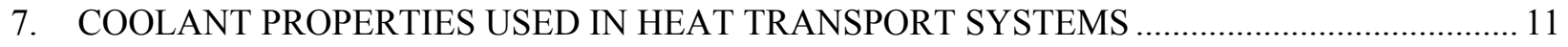

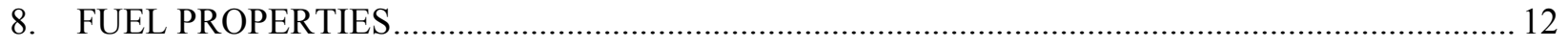

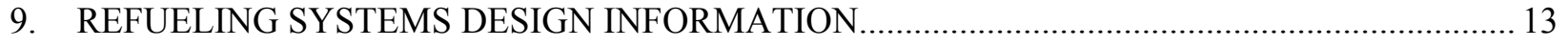

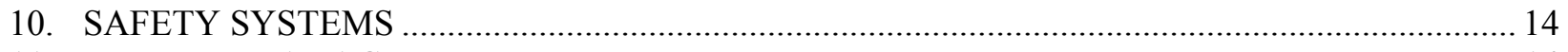

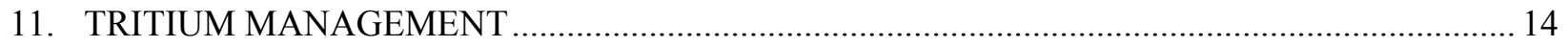

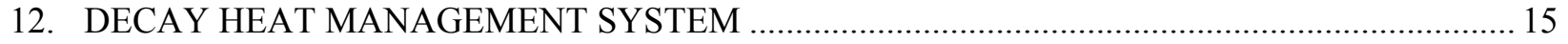

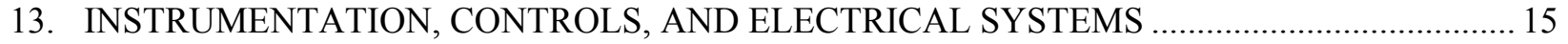

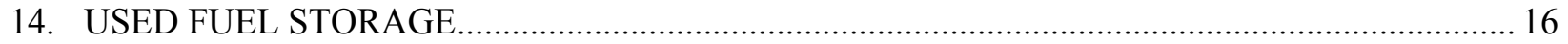

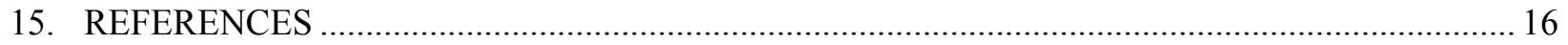

APPENDIX A-REACTOR CONCEPT DESCRIPTION SUMMARY TABLE ................................ A-1

ATTACHMENT B-ADVANCED NUCLEAR TECHNOLOGY CRITERIA WORKSHEET ............ B-1 



\section{LIST OF TABLE AND FIGURES}

Page

Table 1. SmAHTR-CTC key plant design parameters.................................................................. 2

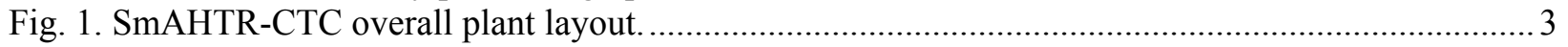

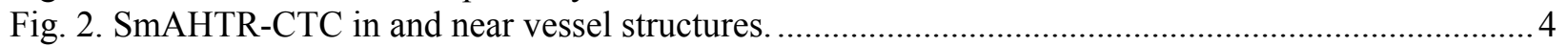

Fig. 3. SmAHTR containment layers (a) physical configuration and (b) conceptual arrangement. .............5

Fig. 4. Uranium carbonate process steps for hydrogen generation. ....................................................... 11

Fig. 5. SmAHTR core cross section showing inter-assembly graphite ................................................... 13 



\section{ACRONYMS}

$\begin{array}{ll}\text { AHTR } & \text { advanced high-temperature reactor } \\ \text { ANS } & \text { American Nuclear Society } \\ \text { ASME } & \text { American Society of Mechanical Engineers } \\ \text { BPVC } & \text { boiler and pressure vessel code } \\ \text { CTC } & \text { carbonate thermochemical cycle } \\ \text { DBA } & \text { design basis accident } \\ \text { DHX } & \text { DRACS heat exchanger } \\ \text { DOE-NE } & \text { US Department of Energy Office of Nuclear Energy } \\ \text { DRACS } & \text { direct reactor auxiliary cooling system } \\ \text { EPZ } & \text { emergency planning zone } \\ \text { FHR } & \text { Fluoride salt-cooled High-temperature Reactor } \\ \text { GDC } & \text { general design criteria } \\ \text { HTGR } & \text { high-temperature gas-cooled reactor } \\ \text { LWR } & \text { light water-cooled reactor } \\ \text { MSRE } & \text { Molten Salt Reactor Experiment } \\ \text { NDHX } & \text { natural draft heat exchanger } \\ \text { NGNP } & \text { Next Generation Nuclear Plant } \\ \text { NPP } & \text { nuclear power plant } \\ \text { NRC } & \text { US Nuclear Regulatory Commission } \\ \text { P-IHX } & \text { primary-to-intermediate heat exchanger } \\ \text { PWR } & \text { pressurized water reactor } \\ \text { R\&D } & \text { research and development } \\ \text { SCRAM } & \text { unclear origin - meaning rapid reactor shutdown } \\ \text { SSCs } & \text { systems, structures, and components } \\ \text { SFR } & \text { sodium-cooled fast reactor } \\ \text { SmAHTR } & \text { Small, modular Advanced High-Temperature Reactor } \\ \text { TRISO } & \text { tri-structural isotropic } \\ & \\ & \end{array}$





\section{FOREWORD}

This report provides equivalent information to that requested by the Department of Energy Office of Nuclear Energy in "Request for Information DE-SOL-0003674" dated February 27, 2012. 



\section{INTRODUCTION}

The US Department of Energy Office of Nuclear Energy's (DOE-NE's) 2010 Nuclear Energy Research and Development Roadmap identifies "Enable New Builds and Improve the Affordability of Nuclear Power" as a major research and development (R\&D) objective. The focus of this report is on describing the attributes, strengths, weaknesses, and relative benefits of the Small, Modular Advanced HighTemperature Reactor (SmAHTR) in terms of enabling construction and licensing of the new reactor concept and improving its economic attractiveness.

SmAHTR is a deliberately small Fluoride salt-cooled High-temperature Reactor (FHR) design concept intended to match the energy requirements of coupled industrial processes. FHRs are an emerging reactor class that combines attractive attributes from previously developed reactor classes. FHRs by definition feature low-pressure liquid fluoride salt cooling, coated particle fuel, and fully passive decay heat rejection. FHRs have the potential to economically and reliably produce high-temperature process heat while maintaining full passive safety. The particular variant of SmAHTR described in this report is designed for efficient hydrogen production using the carbonate thermochemical cycle (CTC). ${ }^{1}$ The SmAHTR-CTC design variant is an evolution of the SmAHTR design concept first described by Greene et al. in $2010 .^{2}$

The technology issues that remain to be resolved prior to FHRs being deployed for commercial power production are described in the FHR technology development roadmap. ${ }^{3}$ In addition to surmounting the technical and licensing barriers to deployment, any advanced reactor requires overcoming the financial challenges that accompany introducing new technology. After decades of development, non-water reactors are not operating at an appreciable scale in the commercial marketplace despite offering advantageous safety characteristics and performance features. Indeed, the British have abandoned (last reactors scheduled for closure in 2023) their carbon dioxide-cooled reactor program in favor of light water reactors (LWRs). The central challenge for any advanced reactor is competing with mature LWRs with their well-understood economics and safety characteristics.

The "new build" strategy being pursued for SmAHTR-CTC has three guiding principles: (1) leverage plant characteristics for maximum economic performance, (2) maximize reliability, and (3) minimize licensing risk. The design intent is to leverage the inherent reactor characteristics to drive down cost while to the extent possible staying within the structure of the current US Nuclear Regulatory Commission (NRC) licensing framework. A key element of the strategy is to rely upon SmAHTR's strong, inherent safety characteristics to avoid the need for expensive, redundant safety structures and systems. Nearly all aspects of FHRs will either be less costly or have costs equivalent to those of LWRs. The major exception to the comparative cost advantage is the markedly higher cost of the primary coolant. Initial FHRs will also incur significant first-of-a-kind expenses. For example, SmAHTR's initial fuel load of tri-structural isotropic (TRISO) coated-particle fuel will cost much more than an equivalent amount of LWR fuel pellets because of the need to construct new manufacturing facilities.

Nuclear power plants (NPPs) can only be economically viable if they operate reliably. Experience has repeatedly and forcefully demonstrated the perils of relying on unproven technology in complex systems. FHRs are significantly technically different from any prior reactor class and at their current maturity level include a number of insufficiently demonstrated technologies. Moreover, the CTC remains at an early development stage. To minimize the technology risk, SmAHTR-CTC development plans include a strong proven technology bias and rely upon progressively developing a solid technical foundation for the innovative features. For example, SmAHTR-CTC will employ overhung cantilever primary pumps, as opposed to the more advanced spool pumps proposed for the IRIS reactor design, and visually guided, off-line refueling using conventional mechanisms. 
Nuclear power is a regulated industry with extensive reliance upon precedent. Requiring regulators to develop a new regulatory framework to accommodate reactor features would be prohibitively expensive and uncertain. However, the NRC's licensing history includes precedents for approving advanced reactors. The Fort Saint Vrain high-temperature gas-cooled reactor (HTGR) was granted an operating license, and the sodium-cooled, fast spectrum Clinch River Breeder Reactor was granted a construction permit under a licensing framework similar in many respects to that extent today. Nevertheless, the increased licensing requirement certainty that is intended to result from the current DOE-NRC joint initiative ${ }^{4}$ on advanced reactor licensing framework development will be relied upon to decrease SmAHTR-CTC's licensing risk.

\section{GENERAL DESCRIPTION OF THE PLANT CONFIGURATION}

SmAHTR-CTC has three principal physical divisions: (1) a below-grade nuclear island, (2) an interconnecting heat transfer loop, and (3) an at-grade hydrogen plant. SmAHTR-CTC's key plant design parameters are summarized in Table 1. An overview diagram of the plant configuration is shown in Fig. 1.

Table 1. SmAHTR-CTC key plant design parameters

\begin{tabular}{ll}
\hline Core thermal power & $125 \mathrm{MW}$ \\
Fuel type & Coated particle (tri-structural isotropic) \\
Core configuration & Cartridge formed from plate assemblies \\
Fissile material & Uranium $\left(8 \mathrm{wt} \%{ }^{235} \mathrm{U}\right)$ \\
Power cycle & $\mathrm{CTC}$ \\
Refueling interval & 6 months $(6 \mathrm{batch})$ \\
Refueling outage minimum duration & 8 hours \\
Core inlet/outlet temperature & $670^{\circ} \mathrm{C} / 700^{\circ} \mathrm{C}$ \\
Peak fuel temperature & $<900^{\circ} \mathrm{C}$ \\
Primary coolant & $\mathrm{LiF}-\mathrm{BeF}_{2}\left(66-34 \mathrm{~mol} \% ; 99.995^{7} \mathrm{Li}\right)$ \\
Intermediate coolant & $\mathrm{KF}-\mathrm{ZrF}_{4}(58-42 \mathrm{~mol} \%)$ \\
$\mathrm{H}_{2}$ production rate & $0.44 \mathrm{~kg} / \mathrm{s}$ at $100 \%$ efficiency \\
Primary pressure & $\mathrm{Near}$ atmospheric \\
Intermediate pressure & $\mathrm{Near}$ atmospheric \\
Carbonate thermochemical cycle (CTC) peak pressure & $<3$ atmospheres \\
\hline
\end{tabular}

\subsection{NUCLEAR ISLAND}

SmAHTR-CTC has an integral, pool-type primary system configuration. The reactor core, primary pump impellers, primary-to-intermediate heat exchangers (P-IHX), and direct reactor auxiliary cooling system (DRACS) heat exchangers (DHX) are all contained within the reactor vessel. The three DRACS loops extend upwards to natural draft heat exchangers (NDHX) located in the base of three separate cooling towers. SmAHTR's reactor vessel will be hung from its upper flange in a stainless steel-lined concrete silo. The stainless steel liner serves as a guard vessel to ensure that even in the event of massive vessel failure the core and decay heat removal systems remain immersed in salt.

Fig. 2 shows the layout of the SmAHTR in-vessel structures. The primary coolant pumps take their suction from the top of the upper vessel plenum. The primary pumps force coolant down the exterior of the core barrel through the shell side of the P-IHXs. The downcomer region is segmented azimuthally into six flow paths, three primary heat transport segments, and three DRACS segments. Coolant flow is 
upwards through the core. The lower core support plate provides flow distribution through the fuel assemblies. SmAHTR-CTC has three primary pumps and a single intermediate pump. The three P-IHXs are fed from a common intermediate loop pipe header. Flow distribution between the intermediate loop segments is controlled using a throttle valve on each pipe section. SmAHTR-CTC does not include a dedicated maintenance shutdown cooling system and is, consequently, intended to be defueled during maintenance activities on the primary heat transport system. Apart from the P-IHX tubes, the primary coolant boundary is thermally insulated and incorporates external electrical heaters.

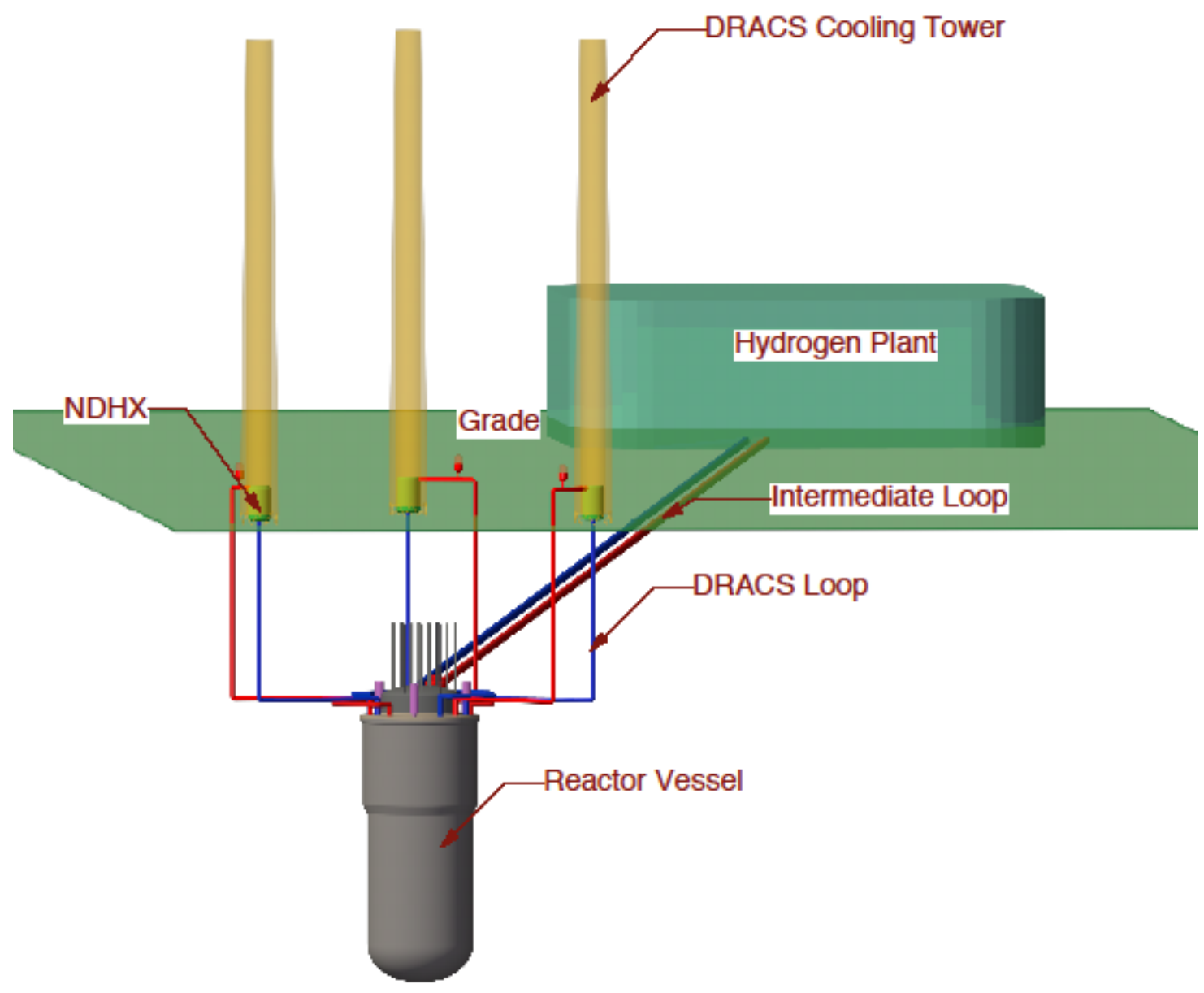

Fig. 1. SmAHTR-CTC overall plant layout.

SmAHTR-CTC has multiple low-leakage containment layers as well as significant inherent radionuclide retention mechanisms. A general nuclear island layout indicating the non-fuel containment layers is shown as Fig. 3a. The radionuclide containment and retention mechanisms are shown conceptually as Fig. 3b. SmAHTR-CTC's radionuclide containment and retention mechanisms are substantially different from LWRs and HTGRs due to the low system pressure and high radionuclide solubility of the primary coolant. The first containment layer is the TRISO silicon carbide layer. The next containment layer is the primary coolant boundary. The P-IHX tube walls are part of the primary coolant boundary. The next containment layer is a low-pressure beryllium and tritium containment layer. The beryllium and tritium containment layer will be a thin $(\sim 1 \mathrm{~cm})$ structural alloy shell. The final containment layer is the flood seal for the below-grade nuclear island. The flood seal containment layer will also be based upon thin structural alloy walls with truss-type reinforcement. The flood containment will also include a flexible joint interconnecting the seismically isolated nuclear island to the surrounding soil at the top of the building hole. 


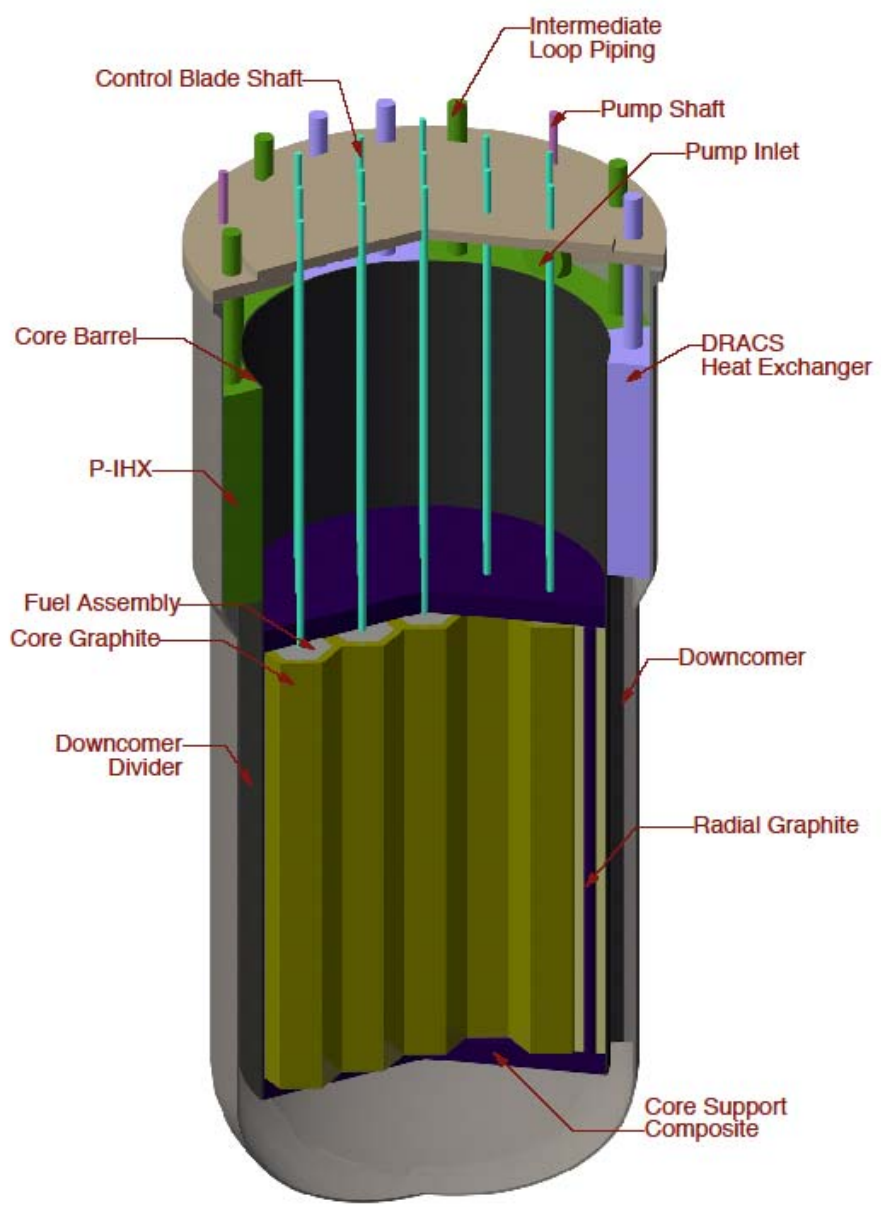

Fig. 2. SmAHTR-CTC in and near vessel structures.

The fuel kernel, the carbon materials surrounding the fuel particles, and the liquid salt coolant inherently trap a substantial fraction of SmAHTR-CTC's radionuclides. Experience with the Molten Salt Reactor Experiment (MSRE) demonstrates that only tritium and the noble fission gases would appreciably evolve out from the salt, with the remainder of the radionuclides either chemically bound into the salt or surrounding carbon, or in the case of noble metals either plated onto salt wetted surfaces or suspended as colloids within the salt. ${ }^{5}$ Effectively, the entire primary coolant functions as a chemical trap for both the actinides and the most radiologically significant fission products.

The intermediate loop fluoride salt would also chemically retain radionuclides that penetrate through the P-IHX boundary. The intermediate loop will penetrate the flood containment. In order to avoid the need for large containment isolation valves, the intermediate loop will be sloped so that its liquid salt contents would drain back toward the reactor in the event of a tube leak adding additional coolant to the reactor vessel.

Tritium is the only radionuclide with a significant escape potential from the primary coolant boundary under normal operating conditions. At high temperatures $\left(>300^{\circ} \mathrm{C}\right)$ tritium readily permeates structural alloys. Tritium will continuously evolve out of the high-temperature portions of the primary coolant containment boundary and will be continuously removed from both the in-vessel cover gas and the beryllium-tritium containment atmosphere via chemical trapping into a metal hydride. The large surface area and thin tubing walls combined with the turbulent mixing within the heat exchanger make tritium escape through the P-IHX tubes, which is a significant tritium escape mechanism. SmAHTR-CTC's 
P-IHXs will have a double-walled shell and tube configuration with primary coolant on the shell side. Tritium can also escape through the DRACS loops. During normal operation, flappers at the entrance and exit of the shell side of each NDHX will be closed. The tritium evolving from the NDHX tubes will be contained within the shell and removed from the shell interior atmosphere by trapping as a metal hydride. The increased temperature of accident conditions will cause the NDHX shell side flappers to open, allowing natural draft airflow through the NDHX. The small amount of resultant tritium release (tritium is only produced in significant quantities while the reactor is operating) will be included in the accident consequence analysis.

(a)

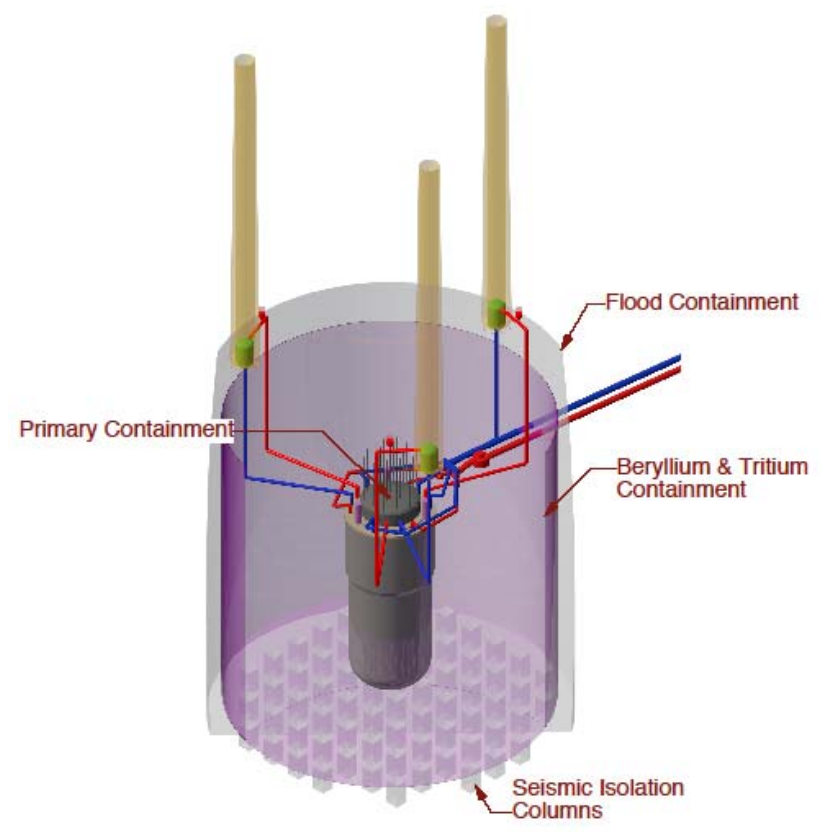

(b)

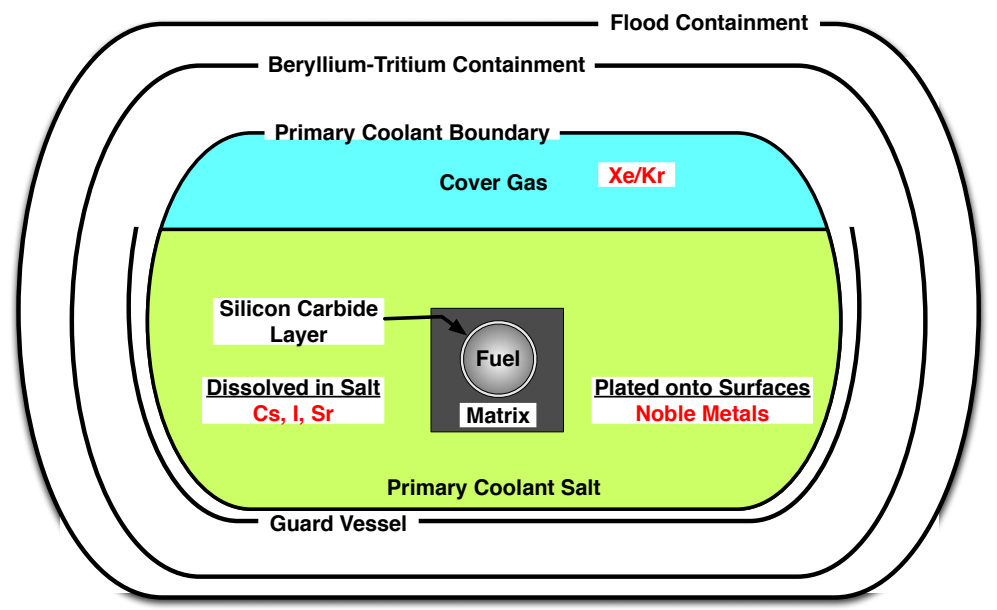

Fig. 3. SmAHTR containment layers (a) physical configuration and (b) conceptual arrangement.

In addition to preventing radioactive contamination, SmAHTR-CTC will be required to protect its staff from beryllium exposure. Beryllium fluoride is toxic. The vapor pressure of beryllium fluoride will be a few tens of Pascal at operating temperature. Some amount of beryllium fluoride contamination is anticipated on the exterior surfaces of the materials within the beryllium and tritium containment layer. Staff will require breathing apparatus for any activities performed within the tritium-beryllium containment. The beryllium and tritium containment layer is physically separated from the flood containment layer to minimize the number of components that are within a maintenance environment that 
is difficult to access. Telepresence technologies will be employed to the extent possible to further reduce required staff activities within the beryllium and tritium containment layer.

The SmAHTR-CTC nuclear island includes a used fuel storage pool within the beryllium-tritium containment. SmAHTR-CTC employs a cartridge core configuration wherein the entire core is transferred from the reactor vessel to the used fuel pool as a single unit. The core is comprised of 19 plate-type TRISO fuel assemblies. Used fuel assemblies are kept in the used fuel pool for 6-12 months following their removal from the core. The fuel assemblies will then be transferred to local dry well storage where they can remain for an indefinite period. The used fuel pool has both a passive liquid-metal thermosyphon-type decay heat removal system and a pumped closed cooling loop for normal operations.

\subsection{INTERMEDIATE LOOP}

The SmAHTR-CTC intermediate loop transfers the reactor core's heat to the chemical plant. The loop will nominally be $100 \mathrm{~m}$ in length, but can vary in length according to site requirements, as the plant cost and/or functionality is not strongly impacted by the intermediate loop length. The loop (1) provides substantial physical separation of the nuclear island from the hydrogen production process, (2) mechanically and seismically decouples the nuclear island from the hydrogen plant, (3) extends beyond the primary nuclear security boundary, and (4) is sloped to drain towards the nuclear island in the event of a P-IHX tube leak. The loop also provides the mechanical flexibility necessary to accommodate thermal expansion of nuclear island and hydrogen plant components. The portions of the loop outside of primary containment are intended to be constructed according to power plant piping codes (ASME B31.1) and can thus include design elements such as mechanical bellows to enable accommodating thermal expansion and rupture disks to prevent pressure spikes from propagating along the pipe.

\subsection{HYDROGEN PLANT}

SmAHTR's hydrogen production plant will implement the CTC. The peak cycle temperature is not greater than $650^{\circ} \mathrm{C}$, and the peak pressure is at most a few atmospheres. In the CTC process, uranium valence changes drive the decomposition of water to hydrogen and oxygen. The key innovative step is reacting triuranium octoxide $\left(\mathrm{U}_{3} \mathrm{O}_{8}\right)$ with sodium carbonate $\left(\mathrm{Na}_{2} \mathrm{CO}_{3}\right)$ and steam to generate hydrogen and sodium diuranate $\left(\mathrm{Na}_{2} \mathrm{U}_{2} \mathrm{O}_{7}\right)$ at $\leq 650^{\circ} \mathrm{C}$. ${ }^{6}$ The reaction is suitable for implementation in a screw calciner. The relatively narrow and variable energy gap, between uranium's $6 d$ and $5 f$ atomic orbitals, enables uranium to assume more than one valence state under relatively mild temperatures and pressures. Shifting uranium's oxidation state liberates the hydrogen from the steam. The cycle process steps necessary to regenerate $\mathrm{U}_{3} \mathrm{O}_{8}$ and $\mathrm{Na}_{2} \mathrm{CO}_{3}$ from $\mathrm{Na}_{2} \mathrm{U}_{2} \mathrm{O}_{7}$ are already industrially implemented in the uranium processing industry. However, the CTC to date has only been demonstrated at laboratory scale.

The physical chemistry (change in enthalpy and chemical equilibrium constant) of each of the required steps in the CTC (see equations 1-3 in Sect. 5) are drawn from known thermochemical properties. Combining the known process energetics of each of the chemical reactions yields a theoretical energy requirement of $284 \mathrm{~kJ} /\left(\mathrm{g}-\mathrm{H}_{2}\right)$. The efficiency of a thermochemical cycle is reduced from its ideal value by the energy losses required to operate the processing equipment. In general, higher temperatures result in higher heat losses from the plant and higher pressures require more energy for the compression and pumping. The CTC requires markedly lower temperatures $\left(650^{\circ} \mathrm{C}\right.$ vs $\left.850^{\circ} \mathrm{C}\right)$ and pressures $(3 \mathrm{~atm}$. vs $35 \mathrm{~atm}$.) than the sulfur iodine cycle, which has a projected thermal efficiency of $51 \%{ }^{7}$ and consequently is anticipated to have substantially higher thermal efficiency.

Assuming an ideal system gives a general idea of the size of the required components, each molecule of hydrogen requires three uranium atoms per cycle. For an assumed cycle time of 1 hour, SmAHTR-CTC's $125 \mathrm{MW}(\mathrm{t})$ yields roughly 1.6 tons of hydrogen per hour, which requires 562 tons of uranium in the cycle. 
Worldwide more than a million tons of depleted uranium is available at low or no cost as a waste product of the uranium enrichment industry. $\mathrm{U}_{3} \mathrm{O}_{8}$ has a density of $8.3 \mathrm{~g} / \mathrm{cm}^{3}$, yielding a component volume of $\sim 80 \mathrm{~m}^{3}$. The entire process volume will, therefore, be on the order of a few hundred cubic meters.

\section{PRINCIPAL DESIGN CRITERIA}

The safety characteristics of FHRs arise from fundamental physics and well-designed, constructed, and maintained SSCs. Until an approved set of reactor-class-specific general design criteria GDCs, as well as design basis accident (DBA) sequences, is available, a combination of engineering judgment and the safety characteristics of FHRs will be relied upon to guide SmAHTR-CTC's design. FHRs feature full passive safety and do not require any active system or operator response to avoid large off-site release for any postulated accident with non-trivial probability (e.g., apart from acts of war, meteorite strikes, etc.).

The silicon carbide barrier layer of properly operating coated-particle fuel will remain intact several hundred degrees above SmAHTR-CTC's peak fuel temperature, retaining nearly all of the fission fragments. The primary FLiBe coolant will not boil until it reaches temperatures over $1400^{\circ} \mathrm{C}$. SmAHTR's core outlet temperature is $700^{\circ} \mathrm{C}$. Additionally, while the power density of FHR cores is above that of HTGRs, FHRs contain larger numbers of fuel particles, resulting in low average particle power (26.5 mW/particle for SmAHTR-CTC as compared to $\sim 150 \mathrm{~mW} /$ particle for the NGNP). ${ }^{9}$

The reactor vessel does not include any penetrations below $\sim 20 \mathrm{~cm}$ above the top of the DRACS heat exchangers. Fluoride salts have high volumetric heat capacity, and a large volume of salt is maintained over the core, providing a substantial thermal margin. The strong overall reactor negative reactivity temperature feedback will prevent reactivity insertion accidents from causing the fuel damage. The negative Doppler fuel temperature coefficient for fresh fuel is similar in magnitude to that of a typical pressurized water reactor (PWR). ${ }^{10}$ The coolant temperature feedback coefficient is also negative, but one order of magnitude smaller than the negative Doppler feedback, while the moderator temperature coefficient is near zero.

SmAHTR-CTC's most thermally sensitive component is its reactor vessel. Exceeding the reactor vessel's design temperature for long periods of time would increase its creep. However, creep is not a threshold process, and SmAHTR-CTC's reactor vessel creep budget would allow for hundreds of hours of operational time several tens of degrees above normal. The ability of the vessel, core, and coolant to tolerate temperature rises enables the use of thermal triggers to provide negative reactivity feedback. SmAHTR-CTC's control blades feature thermal fuses (melt point alloys) located in the upper plenum that are designed to release the blades in the event of an over-temperature accident without SCRAM. Also, SmAHTR's secondary shutdown poison salt accumulators will be set to inject poison salt into the core inlet plenum in the event of more severe temperature excursions.

SmAHTR employs natural circulation DRACS-type decay heat rejection to the local air. Fluoride salts have large coefficients of thermal expansion that combined with their large volumetric heat capacities enable excellent natural circulation cooling. Similar natural-circulation-driven emergency heat rejection is also provided to the used fuel storage pool. The DRACS are modular and independent, enabling the system to continue to function following the failure of individual units. SmAHTR-CTC's design calls for three independent DRACS and is intended to withstand DBAs with only two out of three systems in operation. 


\section{ECONOMICS}

SmAHTR-CTC's objective is to economically and safely produce hydrogen and thereby maximize the return on investment to the plant owners. A key element in ensuring advantageous economic performance is minimizing the risk premium element of the interest rate paid on funds borrowed to construct the plant. The interest rate risk premium is determined based upon how confident a lender is that an FHR plant (1) will be constructed at planned cost and schedule, (2) will obtain regulatory approval to operate, and (3) will operate reliably for many years. SmAHTR-CTC's design is not yet mature enough to develop a "bottoms-up" cost model. Consequently, the economic evaluation is limited to comparison with similar technologies.

All nuclear reactors produce heat. All currently operating commercial NPPs use that heat to generate electricity. In particular, LWRs are a mature technology for electricity production. SmAHTR is a hightemperature reactor, which would enable it to either have a higher thermal efficiency for electricity production or to produce high-temperature process heat. LWRs cannot efficiently serve the hightemperature industrial process heat market. SmAHTR-CTC's design is, therefore, optimized to provide high-temperature process heat, avoiding initial competition with mature technology. The hightemperature process heat market introduction strategy is also being pursued by the Next Generation Nuclear Plant (NGNP) Alliance for similar reasons. US Secretary of Energy Dr. Ernest Moniz has recently endorsed this strategy, stating that "Small modular reactors, especially high temperature ones, may have a particular role essentially as heat sources."11

Maximizing SmAHTR-CTC's economic performance is structured around its three "new build" guiding principles.

\subsection{LEVERAGING PLANT CHARACTERISTICS}

Both SmAHTR-CTC's inherent and engineered features are intimately involved with the plant's economic performance. Specific costs estimates are not yet available, as SmAHTR-CTC's design has not yet reached an adequate level of maturity. However, the plant features are similar to those of more mature reactor classes, allowing cost comparisons to be made with known technologies.

Manufacturing large-diameter, thick-walled components is a major expense for both LWRs and HTGRs because of both technical difficulties in fabricating large-diameter forgings and limited supplier competition. High-pressure containments are expensive. FHRs lack mechanisms to pressurize containment. FHRs do not include large quantities of water within containment, and thus avoid the potential for steam phase change or hydrogen generation/explosion-class accidents.

The strong chemical trapping of radionuclides by the fuel structure and primary coolant as well as the multi-layer containment boundaries results in a much smaller source term under accident conditions than an equivalent thermal power LWR. The size of the emergency planning zone (EPZ) surrounding an NPP is based upon the predicted amounts of radionuclides released into the environment in evaluated beyond DBAs. SmAHTR-CTC has a much smaller potential source term and thus will have a much smaller EPZ.

The only aspect of FHRs that has been identified to date that will cost substantially more than other reactor classes is their more expensive primary coolant. SmAHTR-CTC will require $\sim 16$ tons of isotopically selected $(\sim 99.995 \%){ }^{7} \mathrm{Li}$. Developing a reliable, cost-effective supply of ${ }^{7} \mathrm{Li}$ is thus necessary for FHRs to be economically preferable. From the 1950s through the 1960s, the United States produced industrial quantities of isotopically separated lithium (using a currently environmentally unacceptable mercury-based separation technique) at a reasonable cost with expectations for significant cost reduction with increasing production volume. Lithium isotopes can be separated using conventional chemical 
technologies with higher separation coefficients than the historic mercury-based technique and wellunderstood cost-vs-production volume cost scaling relationships.

Much as with HTGRs, SmAHTR-CTC's lower core power density, robust materials, and large margins to failure alleviate the potential for rapidly evolving accidents. Consequently, rapidly responding safety systems are not required. In particular, slowly evolving accidents enable the plant operators to provide a diverse additional layer of defense-in-depth to safety systems.

FHR TRISO will likely be much less expensive than HTGR TRISO because of the difference in fuel safety classification between the two reactor classes. A design objective for SmAHTR-CTC is to meet the requirements for adequate large release frequency performance without relying on the fuel particle radionuclide retention capabilities. Nuclear-safety-related systems, structures, and components (SSCs) cost much more than identical non-safety-related SSCs. FHRs, in marked contrast to HTGRs, will not rely on the TRISO fuel radionuclide retention capabilities to achieve any safety objective.

The combination of SmAHTR's high primary coolant specific heat and high core outlet temperature results in high energy availability. Nearly all chemical processes have minimum temperature thresholds to become energetically favorable. In particular, the CTC requires up to $650^{\circ} \mathrm{C}$ in its high-temperature heat input step, and thus its temperature threshold is well suited to efficiently coupling to FHRs. LWRs would only be able to support the CTC (or high-temperature steam electrolysis or the sulfur iodine thermochemical cycle) by supplementing their heat with electricity, which is not economically feasible.

The higher exergy also improves the plant compatibility with low- or no-water cooling, which significantly increases the plant siting locations while decreasing the land acquisition cost. The efficiency of any thermal cycle is based upon the temperature ratio between its hot and cold reservoirs. Raising the heat rejection temperature, to reduce the cost of an air-cooling system, therefore, has a smaller impact on the thermal efficiency of a higher temperature cycle.

The uranium density for graphite-moderated cores is less than that for water-moderated cores because the macroscopic slowing down power for carbon is $\sim 17$ times lower than that for water. Consequently, graphite moderated cores either need to be larger with lower power density, have a higher enrichment, and/or more frequently replace their fuel. SmAHTR-CTC will use a combination of these techniques. The lower amount of fuel (radionuclides) in core at any time decreases the potential accident source term, helping to enable refueling to begin shortly after shutdown.

SmAHTR-CTC takes rapid refueling one step further by replacing its entire core as a single unit. TRISO fuel is thermally robust and does not have a failure mode equivalent to the pellet clad interaction that limits the rate of power rise in LWRs. The design intent is to replace SmAHTR-CTC's core in a single shift and rapidly return to full power, largely avoiding the significant impact refueling could have on plant availability.

\subsection{MAXIMIZE RELIABILITY}

Developing confidence in the likelihood of FHRs to reliably operate is a significant impediment to commercial deployment. Advanced reactors have historically had low capacity factors, making them highly uneconomical. No market economy has succeeded in introducing non-water-cooled reactors on a commercial basis at an appreciable scale. Indeed, external evaluation has repeatedly indicated that "apparent cost is the constraint that prevents nuclear and renewable energies from fully supplanting fossil fuel electricity generation." ${ }^{\prime 15}$ LWRs are a reliable, mature reactor technology with an established cost and performance basis. Significant effort from the 1970s through the 1990s was required for LWRs to achieve 
their current high level of reliability and availability. Shortening the equivalent FHR learning curve is a principal development objective for SmAHTR-CTC.

SmAHTR-CTC will rely on proven technology operating well within stress limits whenever possible. The inherent reactor-class properties facilitate minimizing component stresses. SmAHTR-CTC's relatively low core power density and high coolant heat capacity enable a lower primary coolant core flow velocity $(<2 \mathrm{~m} / \mathrm{s})$, which minimizes the potential for flow-induced vibration. The transparent, single-phase coolant enables remotely locating process monitoring instrumentation within a relatively benign environment. A key element of SmAHTR-CTC's development strategy is systematically developing and demonstrating the required technologies as early as possible. Important FHR technologies such as primary coolant cleanup and modern lithium isotope separation techniques have only been demonstrated at the laboratory scale and have significant remaining uncertainties for industrial use. To minimize the impact of technology immaturity, SmAHTR-CTC shifts as much development risk as possible from plant construction and operations to manufacturing (e.g., lithium isotope separation and TRISO production) that can be resolved prior to initiating construction.

\subsection{MINIMIZE LICENSING RISKS}

Developing confidence that SmAHTR-CTC can be licensed at a predictable cost and schedule is a key aspect of minimizing the development risk. Minimizing SmAHTR-CTC's licensing risk has three key elements: (1) complying with established licensing precedent, (2) following the NRC's guidance on advanced reactor licensing, and (3) avoiding requiring the NRC to address unresolved licensing issues.

All current and prior US commercial nuclear power plants (NPPs), including prior advanced plants, were granted licenses through demonstrating compliance with deterministic licensing requirements. SmAHTRCTC will follow the established precedent by employing a risk-informed, performance-based, DBAbased design approach as currently recommended by the NRC. ${ }^{16}$

\section{THERMAL POWER CONVERSION SYSTEM}

SmAHTR-CTC's thermal power conversion system splits water to produce hydrogen. The cycle begins by the thermal reduction of water accompanied by the oxidation of uranium in the presence of sodium carbonate. ${ }^{6}$

$$
2 \mathrm{U}_{3} \mathrm{O}_{8}+2 \mathrm{H}_{2} \mathrm{O}+3 \mathrm{Na}_{2} \mathrm{CO}_{3} \stackrel{650^{\circ} \mathrm{C}}{\longrightarrow} 3 \mathrm{Na}_{2} \mathrm{U}_{2} \mathrm{O}_{7}+2 \mathrm{H}_{2}+3 \mathrm{CO}_{2} \text {. }
$$

Both gaseous products evolve out as the components are heated, and the carbon dioxide is separated from the hydrogen using a separation membrane. The resulting sodium uranate is then cooled and dissolved in ammonium carbonate to form uranyl tricarbonate.

$$
\mathrm{Na}_{2} \mathrm{U}_{2} \mathrm{O}_{7}+4\left(\mathrm{NH}_{4}\right)_{2} \mathrm{CO}_{3}+3 \mathrm{CO}_{2} \stackrel{25^{\circ} \mathrm{C}}{\longrightarrow} 8 \mathrm{NH}_{4}+2 \mathrm{UO}_{2}\left(\mathrm{CO}_{3}\right)_{3}+\mathrm{Na}_{2} \mathrm{CO}_{3} \text {. }
$$

An anion exchange resin is then employed to separate the sodium carbonate from the ammonium uranyl tricarbonate. The ammonium uranyl tricarbonate is then thermally decomposed to reconsititute $\mathrm{U}_{3} \mathrm{O}_{8}$, generating oxygen in the process.

$$
24 \mathrm{NH}_{4}+6 \mathrm{UO}_{2}\left(\mathrm{CO}_{3}\right)_{3} \stackrel{400^{\circ} \mathrm{C}}{\longrightarrow} 24 \mathrm{NH}_{3}+2 \mathrm{U}_{3} \mathrm{O}_{8}+18 \mathrm{CO}_{2}+12 \mathrm{H}_{2} \mathrm{O}+\mathrm{O}_{2} \text {. }
$$


Apart from the oxygen, all of the intermediate products are recycled. The overall process is shown in Fig. 4.

While SmAHTR-CTC's hydrogen production cycle will inherently have high efficiency due to its comparatively low temperature and pressure requirements, process flowsheets have not yet been developed. Consequently, neither a plant layout nor a credible industrial efficiency prediction is yet available.

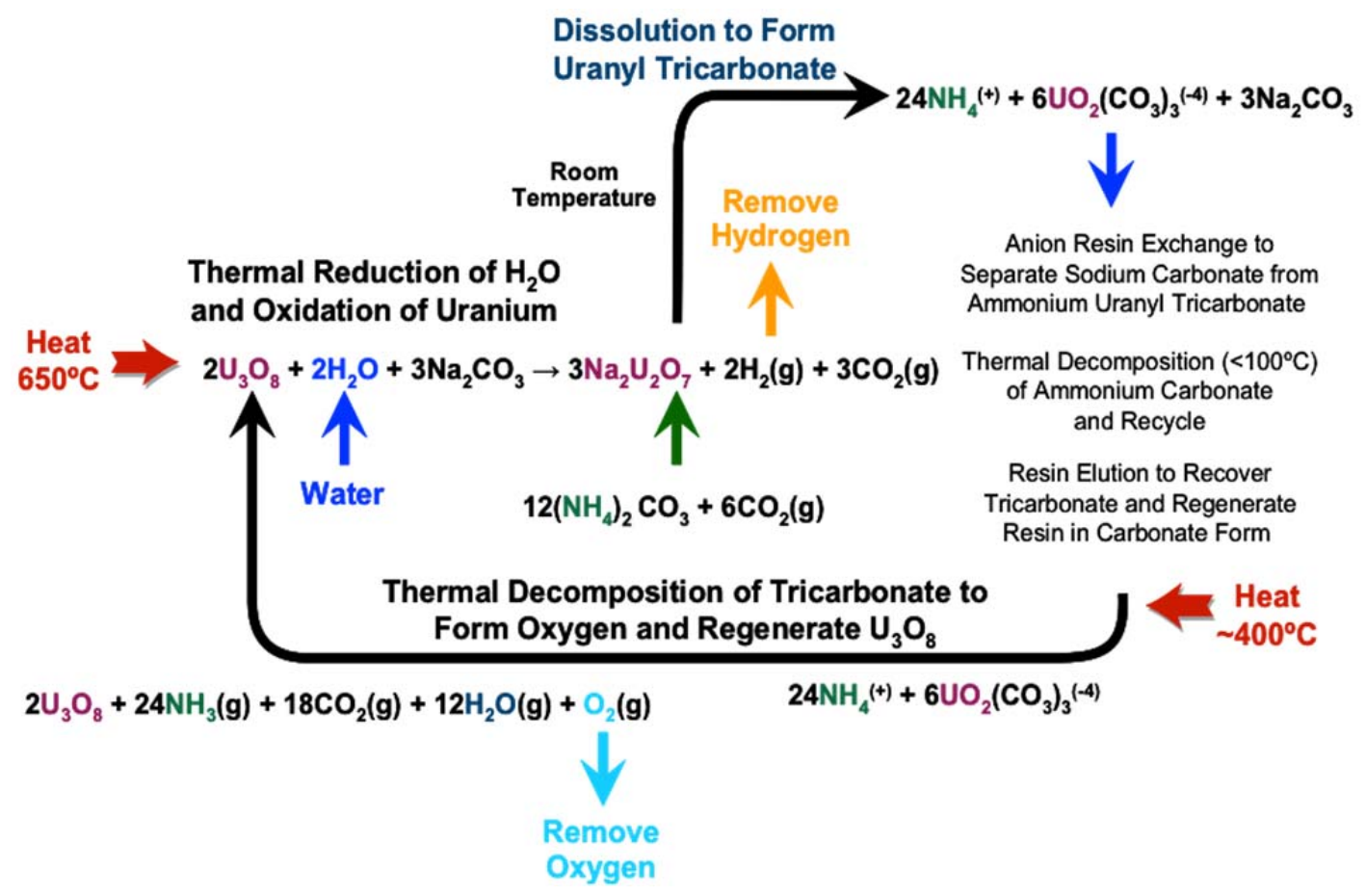

Fig. 4. Uranium carbonate process steps for hydrogen generation.

\section{CONSTRUCTION TECHNIQUES}

SmAHTR-CTC will employ modular construction, with all of the major components small and light enough for factory fabrication and transport to the site via road or rail shipment. Open top-type construction (the major components are first lifted into place and the building top added later) will be employed. Both the beryllium-tritium and flood containment layers feature truss-based thin steel tops that can be lifted away to enable major maintenance. SmAHTR-CTC does not have any thick-walled components. All of the SSCs (including the reactor vessel and civil structures) are designed for eventual replacement resulting in an indefinite plant life.

\section{COOLANT PROPERTIES USED IN HEAT TRANSPORT SYSTEMS}

SmAHTR-CTC will use lithium beryllium fluoride as its primary coolant. FLiBe melts at $458^{\circ} \mathrm{C}$ and boils at over $1400^{\circ} \mathrm{C}$. FLiBe's volumetric heat capacity is $4.67 \mathrm{~J} / \mathrm{cm}^{3}-\mathrm{K}$, its thermal conductivity is $1.0 \mathrm{~W} / \mathrm{m}-\mathrm{K}$, its thermal expansion coefficient is $66 \times 10^{-6} \mathrm{~m} / \mathrm{m}-\mathrm{K}$, and its dynamic viscosity is $5.6 \mathrm{mPa}$-s all at $700{ }^{\circ} \mathrm{C} .{ }^{17} \mathrm{SmAHTR}-\mathrm{CTC}$ will use the low melt point eutectic of $\mathrm{KF}$ and $\mathrm{ZrF}_{4}(58-42 \mathrm{~mol} \%$ ) for both its DRACS and intermediate cooling loops. $\mathrm{KF}^{-} \mathrm{ZrF}_{4}$ melts at $390^{\circ} \mathrm{C}$ and has a volumetric heat capacity of 
$2.93 \mathrm{~J} / \mathrm{cm}^{3}-\mathrm{K}$, a thermal conductivity of $0.45 \mathrm{~W} / \mathrm{m}-\mathrm{K}$, and a dynamic viscosity of $\sim 5.1 \mathrm{mPa}-\mathrm{s}$ at $700^{\circ} \mathrm{C}$. Both the primary and intermediate cooling loops will be operated at near atmospheric pressure.

Beryllium fluoride is toxic but has a low vapor pressure $(<100 \mathrm{~Pa}$ at operating temperature) and is not readily accessible inside of containment. The fuel decay heat and the large coolant volume heat make freezing the primary coolant unlikely. Both the DRACS and intermediate cooling loops would be vulnerable (especially in their heat rejection heat exchangers) to coolant freezing accidents. Under normal operating conditions, the cooling loops have a margin of a few hundred Kelvin to freezing.

Neutron interactions with the primary coolant will generate tritium. The tritium will readily permeate the primary coolant boundary due to the high temperature. As described in Sect. 2, a combination of chemical traps and low-temperature tritium containment layers will be employed to prevent significant escape.

The primary coolant has more than $700 \mathrm{~K}$ of margin to boiling under normal operating conditions and does not have any significant activation products with a half-life longer than 30 seconds. Both the primary and intermediate coolants are chemically inert and will not react strongly with the CTC materials if a heat exchanger leak were to occur.

The primary coolant will dissolve and retain all of the released non-noble fission products. The noble metals will either be chemically retained by the carbon fuel bodies, plate out onto salt-wetted structures, or be maintained as suspended colloids within the salt. FLiBe is not significantly corrosive towards nickel alloys or carbon but will readily dissolve surface oxide layers. If the primary coolant is contaminated with significant quantities of electronegative impurities, it will become strongly oxidative (corrosive). Oxygen is especially problematic. Achieving and maintaining adequate coolant purity (tens of ppm of dissolved oxygen) is a key operational parameter. The primary coolant chemistry control system will employ both hydrogen fluoride sparging to remove dissolved oxygen and contacting with metallic beryllium to maintain the salt in a slightly reducing condition.

The primary coolant cleanup system will be based upon bismuth-lithium reductive extraction. Reductive extraction has been shown to remove both fissile materials and fission products from FLiBe with high separation efficiency. ${ }^{18}$ However, a reductive extraction system has not been demonstrated beyond the laboratory scale. Operation of the reductive extraction system will generate radioactive waste as leaking fission products and/or activated materials are extracted from the primary coolant. SmAHTR-CTC's cleanup system radioactive waste will be packaged and handled in a manner similar to an LWR's resin beds.

\section{FUEL PROPERTIES}

SmAHTR uses TRISO coated-particle fuel embedded near the surface of carbon plates. SmAHTR uses the uranium oxycarbide TRISO fuel particles currently being tested under the advanced gas reactor fuel development program. The fuel particles are located near the surface of the plates to lower the peak particle temperature by improving the thermal coupling to the coolant. The plates are configured into hexagonal assemblies with 18 plates per assembly. SmAHTR's fuel assemblies will closely resemble shortened versions of those for the larger advanced high-temperature reactor (AHTR). ${ }^{19}$ The fuel assemblies will be mounted together into a cartridge core using continuous fiber composite core support plates. SmAHTR's cartridge core enables filling the inter-assembly volume with nuclear-grade graphite, resulting in improved neutron utilization, as shown in Fig. 5. The entire core will be lifted out as a single unit for refueling. Each fuel assembly includes a molybdenum hafnium carbide control blade. While plate-style TRISO fuel bodies have not been manufactured previously, the manufacturing process steps of any geometric shape fuel body are nearly identical. 
SmAHTR-CTC's transparent, low-pressure coolant enables refueling to be performed rapidly using conventional mechanical manipulation technology that is visually guided from above. To refuel, the reactor is first brought subcritical by inserting the control blades. Once the blades have been inserted, the reactor vessel lid can be removed. The core can then be moved via an overhead crane system into the used fuel pool. The thermally robust nature of coated-particle fuel significantly eases the fuel transfer safety design requirements. Even just a few hours after shutdown, the core can withstand more than 15 minutes of removal from liquid cooling, during the fuel transfer process, without exceeding its allowable maximum temperature.

SmAHTR-CTC uses a shielded fuel transfer ramp mechanism conceptually derived from the Phénix SFR fuel-handling system. ${ }^{20}$ Once the reactor vessel top has been removed, a shielded ramp is positioned (using a rail system) with its entrance over the top of the reactor vessel. The core is raised out of the vessel and up the ramp using an overhead crane and upon reaching the top of the ramp is allowed to swing to its opposite side. The core is then lowered into the used fuel pool sliding down the far side of the ramp. The core-lifting mechanism includes a thermal fuse, so that if at any point during the fuel transfer the maximum allowable temperature is exceeded, the core would be passively released to slide downward into a cooled configuration.

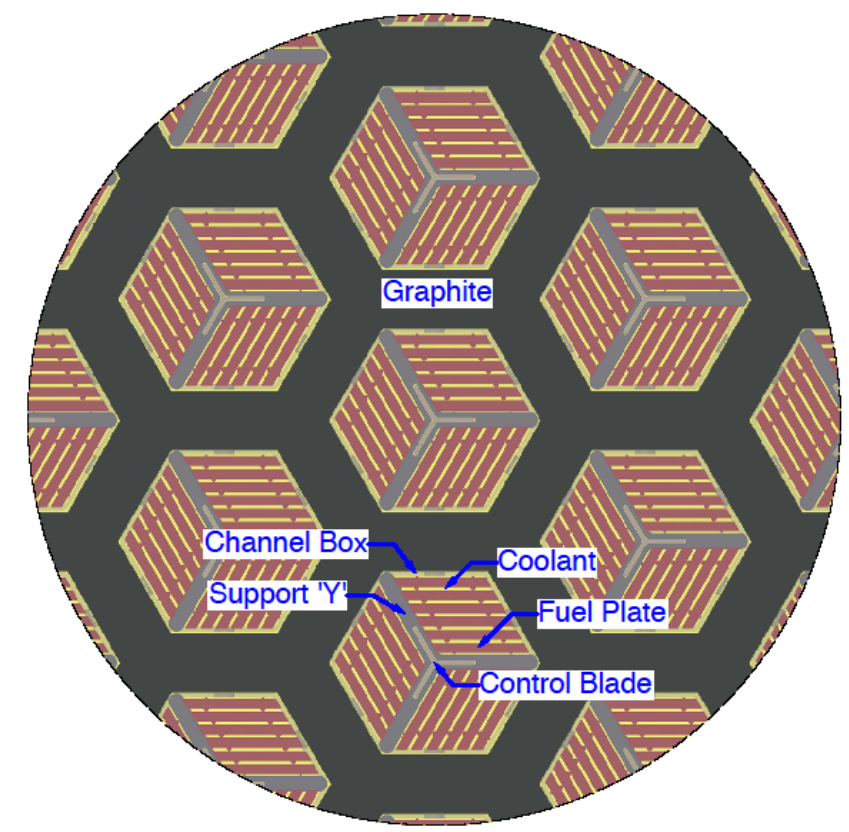

Fig. 5. SmAHTR core cross section showing inter-assembly graphite.

\section{REFUELING SYSTEMS DESIGN INFORMATION}

SmAHTR-CTC employs a twin cartridge-core configuration. A cartridge configuration enables the core to be moved as a single unit, minimizing the number of mechanical manipulations required for refueling. In a twin core system, one core is in the reactor vessel and the other is in the used fuel pool. The twin core configuration enables assembly-level fuel shuffling to be performed while the alternate core is in operation. SmAHTR's core needs to be moved as a single unit due to the tight clearances of its structural elements. Some radiation-induced mechanical distortion will occur during operation. The mechanical distortion will prevent removing individual fuel assemblies from the top. The core internal graphite pieces will be replaced as the fast neutron fluence causes excessive mechanical distortion (every few years). Separating the fuel from the graphite moderator enables separately disposing of the in-core graphite and 
the fuel assemblies, decreasing the volume of high-level waste. SmAHTR-CTC maximizes its neutronic efficiency by maximizing the amount of carbon in the core while minimizing the amount of FLiBe.

SmAHTR's relatively high neutronic efficiency (for a small reactor) enables a number of appealing fuel cycle options. The selected baseline case is to employ $98.8 \mathrm{~kg}$ of $8 \mathrm{wt} \%$ enriched fresh fuel in each of the 19 fuel assemblies. Three (or four) fuel assemblies will be replaced at 6-month refueling intervals. While maintenance activities may extend outages, the refueling performance goal is for single shift core exchange. Another potentially appealing fuel cycle option is to maximize the refueling interval though increasing the fuel enrichment. A refueling interval of up to 8 years can be obtained using $19.75 \mathrm{wt} \%$ enriched fuel in a once-through fuel cycle. SmAHTR-CTC also appears to be neutronically viable using $5 \mathrm{wt} \%$ enriched uranium. However, in this case, twice as many fuel particles would be required in core, effectively converting the fuel plates into large fuel compacts. The impact of fully loading the plates with fuel on the plate structural integrity remains unknown. Moreover, a $5 \mathrm{wt} \%$ enrichment fuel cycle would require full core replacement after about a year and a half, which would significantly reduce the achievable fuel burnup.

\section{SAFETY SYSTEMS}

Apart from the DRACS-based decay heat removal systems described in Sect. 12, SmAHTR-CTC's only safety systems are its reactivity control systems. No accidents have been identified to date that require operator or active system intervention. However, the plant operators can activate both the primary and reserve shutdown systems. The primary shutdown system is the control blades. The control blades have melt point fuses that are located in the upper vessel plenum. If the temperature in the upper plenum exceeds the fuse melt point, the control blades will be released to fall into the core. The control blades feature a second automatic release mechanism. The blades are actively engaged to the drive motors. Upon loss of power the engagement would be released, enabling the control blades to drop into the core. The reserve shutdown system is based on poison salt (rare earth fluoride) that is maintained in a piston-type pressurized accumulator in the lower vessel plenum. If the temperature of the lower plenum were to increase unacceptably, the melt point fuses on the accumulator lid would release, inserting large negative reactivity.

\section{TRITIUM MANAGEMENT}

Tritium management is a central element of FHR operation and therefore is described in the overall plant description section. SmAHTR-CTC will produce 3-5 mg of tritium per day. The lower estimation corresponds to the tritium generated in the core's volume. The higher number is an estimate of the total tritium produced in the coolant if no additional thermal flux shielding is employed. SmAHTR-CTC uses a two-pronged approach to prevent tritium release into the environment. Tritium that emerges from the primary coolant will be trapped by flowing the containment and cover gases through a chemical trap. Noble gas-entrained tritium readily forms stable hydrides when brought in contact with most metals. Consequently, the cover gas, containment, and NDHX atmosphere control systems will each include tritium traps as part of their chemistry control systems. Penetration of tritium through the P-IHX tubing will be blocked by trapping the dissolved gas as a stable yttrium tritide within the gap provided by a double-walled heat exchanger. While double-walled heat exchangers have now become industrially available and are anticipated to be employed to minimize the potential for sodium-water reactions in SFRs, a design incorporating a tritium trap has not yet been developed. 


\section{DECAY HEAT MANAGEMENT SYSTEM}

SmAHTR-CTC's normal core decay heat removal is via the intermediate cooling loop to the balance of plant heat rejection system. During maintenance shutdowns, SmAHTR-CTC's core will be removed to the used fuel cooling pool. Decay heat will be removed via the three independent DRACS cooling loops under loss of forced flow accident conditions. The DRACS cooling loops transfer heat from the DHXs located within the reactor vessel to the NDHXs located at the base of chimneys external to the reactor building. Each NDHX is located within its own chimney to avoid common vulnerability to a single external impact. During normal operation the NDHX is contained within an insulated shell to minimize the parasitic heat loss, and resultant potential for freeze-up, and to enable tritium capture within the NDHX shell.

Each DRACS loop is sized to provide $\sim 0.5 \%$ of full power heat rejection under fully developed flow conditions at $700^{\circ} \mathrm{C}$. Only two of the three DRACS loops are required to protect against an unacceptable temperature rise following or during a protected loss of forced flow accident. The ultimate heat sink is outside air.

Used fuel pool normal-condition cooling is provided via a pumped salt loop to a forced convection heat exchanger coupled to the outside air. Safety-grade heat rejection is provided for the used fuel pool through a two-phase, reduced-pressure, liquid-metal thermosyphon tube wall with the hot ends of the tubes dipped into the used fuel pool and the condenser section above the top of the containment structures.

\section{INSTRUMENTATION, CONTROLS, AND ELECTRICAL SYSTEMS}

Fluoride salts are transparent, and FHRs operate well below the coolant boiling point. The current design intent is to rely upon the transparency for a substantial portion of the reactor instrumentation. The ability to locate sensor materials away from the harsh reactor core environment is a significant operational advantage for FHRs. However, the use of optically based instrumentation at SmAHTR-CTC has unresolved technology issues such as ensuring that in-vessel windows and mirrors remain transparent or reflective. In addition, the means to maintain visual alignment throughout the reactor life cycle and to accommodate the motion of the primary coolant surface will need to be developed and demonstrated. The use of free space optical instrumentation coupling for the most part avoids the necessity for instrument guide tubes, which decreases the complexity of the upper plenum area and enables more rapid refueling.

SmAHTR-CTC will follow the demand requests of the CTC hydrogen plant. An integrated control model has not yet been developed for coupling the plants. However, SmAHTR-CTC does not have any abrupt process transitions (i.e., a need to avoid boiling or flow instabilities) or fuel vulnerabilities to rapid power shifts (e.g., pellet clad interactions). Consequently, neither control blade movement nor pumping rate changes will have significant rate limits. The nuclear plant will use the upper plenum temperature as the direct process control variable, as preserving the reactor vessel lifetime is the most significant operational constraint.

SmAHTR-CTC will not have safety-grade electrical power requirements apart from the control room habitability systems and the small amount of power necessary to melt the reserve shutdown triggers on demand and operate the reactor monitoring systems. The necessary safety-grade power will be supplied by local batteries.

All of SmAHTR-CTC's salt-filled cooling loops (e.g., primary, intermediate, and DRACS) need to incorporate electrical heaters to enable loading with liquid salt and prevent system freeze-up during extended outages. Consequently, prior to initial start-up and to support long-duration (e.g., weeks) 
outages, SmAHTR-CTC will require external sources of electrical power either from the grid or local generators. All of the heat transport loops also need to be well insulated to minimize parasitic heat loss during normal operation as well as to minimize the start-up heating requirements.

\section{USED FUEL STORAGE}

SmAHTR-CTC will employ an in-containment (i.e., within beryllium-tritium containment layer), belowgrade used fuel storage pool. The used fuel pool will be filled with FLiBe $\left(\sim 40 \mathrm{~m}^{3}\right)$. Fuel assemblies from the twin core not in use will be shuffled, inspected, and replaced while in the used fuel pool. Used fuel assemblies will be stored within the pool for 6-12 months following final removal from the core.

The length of time that liquid cooling is required for used fuel is directly related to the core power density. SmAHTR-CTC's lower core power density results in lower required storage time under liquid cooling. TRISO fuel is not water soluble and preserves its first-level containment upon removal from the core. The silicon carbide containment layer is not anticipated to fail in the more benign ex-core environment.

Local dry wells can provide local storage for an indefinite period. Dry wells are cased and cemented steel tubes extend downward into the ground. The fuel decay heat would be conducted to the surrounding ground.

\section{REFERENCES}

1. J. L. Collins, L. R. Dole, J. J. Ferrada, C. W. Forsberg, M. J. Haire, R. D. Hunt, B. E. Lewis, Jr., and R. G. Wymer, Carbonate Thermochemical Cycle for the Production of Hydrogen, US Patent 7,666,387, B2, February 23, 2010.

2. S. R. Greene, J. C. Gehin, D. E. Holcomb, J. J. Carbajo, D. Ilas, A. T. Cisneros, V. K. Varma, W. R. Corwin, D. F. Wilson, G. L. Yoder, Jr., A. L. Qualls, F. J. Peretz, G. F. Flanagan, D. A. Clayton, E. C. Bradley, G. L. Bell. J. D. Hunn, and P. J. Pappano, Pre-Conceptual Design of a Small Modular Fluoride Salt-Cooled High Temperature Reactor (SmAHTR), ORNL/TM-2010/199, December 2010.

3. D. E. Holcomb, G. F. Flanagan, G. T. Mays, W. D. Pointer, K. R. Robb, and G. L. Yoder, Jr., Fluoride Salt-Cooled High-Temperature Reactor Technology Development and Demonstration Roadmap, ORNL/TM-2013/401, ORNL, Oak Ridge, TN, September 2013.

4. Letter from Glenn M. Tracy, Director of NRC Office of New Reactors to John E. Kelly, DOE Deputy Assistant Secretary for Nuclear Reactor Technologies, 7/9/13, http://pbadupws.nrc.gov/docs/ML1314/ML13141A276.pdf.

5. E. L. Compere, S. S. Kirslis, E. G. Bohlmann, F. F. Blankenship, and W. R. Grimes, Fission Product Behavior in the Molten Salt Reactor Experiment, ORNL-4865, Oak Ridge National Laboratory, Oak Ridge, TN, October 1975.

6. J. Ferrada, J. Collins, L. Dole, C. Forsberg, M. J. Haire, R. Hunt, B. Lewis, R. Wymer, and J. L. Ladd-Lively, "Carbonate Thermochemical Cycle for the Production of Hydrogen," National Hydrogen Association Annual Conference and Hydrogen Expo, Columbia, South Carolina, March 30-April 3, 2009.

7. L. C. Brown, G. E. Besenbruch, K. Schultz, and J. E. Funk, Alternative Flowsheets for the SulfurIodine Thermo-Chemical Hydrogen Cycle, GA-A24266, GA, General Atomics, San Diego, CA, February 2003. 
8. G. F. Flanagan, D. E. Holcomb, and S. M. Cetiner, FHR Generic Design Criteria, ORNL/TM2012/226, Oak Ridge National Laboratory, Oak Ridge, TN, June 2012.

9. J. W. Sterbentz, B. Phillips, R. L. Sant, G. S. Chang, and P. D. Bayless, Reactor Physics-Parametric and Depletion Studies in Support of TRISO Particle Fuel Specification for the Next Generation Nuclear Plant, INEEL/EXT-04-02331, INEEL, Idaho Falls, ID, September 2004.

10. B. Ade, A. Worrall, J. Powers, S. Bowman, D. Mueller, G. Flanagan, and J. Gehin, Safety and Regulatory Issues of the Thorium Fuel Cycle, NUREG/CR-7176, US Nuclear Regulatory Commission, Washington, DC, 2014 (to be published).

11. E. J. Moniz, Presentation to National Academies Keck Futures Initiative (NAKFI) conference "The Future of Advance Nuclear Technologies: Building a Healthier and Safer Planet," November 15-17, 2013.

12. GE-Hitachi Global Laser Enrichment LLC license application revision 7-public version, available at http://pbadupws.nrc.gov/docs/ML1224/ML12242A227.pdf.

13. US NRC, Safety Goals for the Operations of Nuclear Power Plants, 51 FR 28044 (August 4, 1986).

14. Assessment of White Paper Submittals on Fuel Qualification and Mechanistic Source Terms, Revision 1, NRC, Office of New Reactors, Washington, DC, March 2013.

15. James Hansen et al., "Assessing Dangerous Climate Change: Required Reduction of Carbon Emissions to Protect Young People, Future Generations, and Nature," PLoS ONE, 8(12), e81648, December 2013, p. 19.

16. A Proposed Risk Management Regulatory Framework, NUREG-2150, NRC, Washington, DC, April 2012.

17. D. F. Williams, L. M. Toth, and K. T. Clarno, Assessment of Candidate Molten Salt Coolants for the Advanced High-Temperature Reactor (AHTR), ORNL/TM-2006/12, Oak Ridge National Laboratory, Oak Ridge, TN, March 2006.

18. H. Moriyama, M. Miyazaki, Y. Asaoka, K. Moritani, and J. Oishi, "Kinetics of Reductive Extraction of Actinide and Lanthanide Elements from Molten Fluoride into Liquid Bismuth," Journal of Nuclear Materials, 182, 113-117 (1991).

19. V. K. Varma, D. E. Holcomb, F. J. Peretz, E. C. Bradley, D. Ilas, A. L. Qualls, and N. M. Zaharia, AHTR Mechanical, Structural, and Neutronic Preconceptual Design, ORNL/TM-2012/320, Oak Ridge, TN, September 2012, p. 7.

20. Y. Chikazawa, M. Farmer, and C. Grandy, "Technology Gap Analysis on Sodium-Cooled Reactor Fuel-Handling System Supporting Advanced Burner Reactor Development," Nuclear Technology, 165, 270-292 (2009). 



\section{APPENDIX A - REACTOR CONCEPT DESCRIPTION SUMMARY TABLE Small Modular Advanced High-Temperature Reactor-Carbonate Thermochemical Cycle}

\begin{tabular}{|c|c|}
\hline \multicolumn{2}{|c|}{ 1. Nuclear Plant Configuration } \\
\hline Primary system & Integral (pumps, P-IHX and DHX in vessel) \\
\hline Intermediate loop & Yes, $\mathrm{KF}-\mathrm{ZrF}_{4}$ (low melt eutectic) \\
\hline Number of Intermediate loops & 3 \\
\hline Number of Hydrogen production loops & 1 \\
\hline Building characteristics & Below grade, seismically isolated \\
\hline Plant lifetime & Indefinite-all structures designed for replacement \\
\hline \multicolumn{2}{|c|}{ 2. Energy Conversion and Balance of Plant (BOP) } \\
\hline Energy conversion cycle & Uranium carbonate thermochemical cycle \\
\hline $\begin{array}{l}\text { Maximum potential thermal efficiency }\left(\left[\mathrm{g}-\mathrm{H}_{2} / \mathrm{s}\right] /\right. \\
\text { MW }[\mathrm{t}])\end{array}$ & 3.5 \\
\hline Building characteristics & Above-grade $\sim 100 \mathrm{~m}$ from reactor, no seismic isolation \\
\hline \multicolumn{2}{|c|}{ 3. Construction Techniques } \\
\hline General approach & $\begin{array}{l}\text { Factory fabrication of basic modules } \\
\text { On-site module integration in workshop, open-top } \\
\text { installation }\end{array}$ \\
\hline Transportability & $\begin{array}{l}\text { Transportable via either road or rail } \\
\text { Deployable in sites without water access }\end{array}$ \\
\hline \multicolumn{2}{|c|}{ 4. Key Plant Parameters } \\
\hline Thermal power (MW) & 125 \\
\hline Max. potential hydrogen production rate $(\mathrm{g} / \mathrm{s})$ & 441 \\
\hline Plant availability target & $>90 \%$ \\
\hline Primary system pressure & Atmospheric \\
\hline Intermediate system pressure & Atmospheric \\
\hline Hydrogen cycle peak pressure (atm) & 3 \\
\hline Reactor vessel thickness $(\mathrm{cm})$ & 2.5 \\
\hline Reactor vessel diameter (m) & 3.5 \\
\hline Reactor vessel height (m) & 9 \\
\hline \multicolumn{2}{|c|}{ 5. Core Performance and Safety } \\
\hline Core power density $\left(\mathrm{MW}[\mathrm{t}] / \mathrm{m}^{3}\right)$ & 5.3 \\
\hline Core power density in fuelled volume $\left(\mathrm{MW}[\mathrm{t}] / \mathrm{m}^{3}\right)$ & 9.4 \\
\hline Fueled core height $(\mathrm{m})$ & 4.0 \\
\hline Effective fueled diameter $(\mathrm{m})$ & 2.75 \\
\hline Effective fueled diameter for fuelled volume (m) & 2.06 \\
\hline Coolant boiling temperature $\left({ }^{\circ} \mathrm{C}\right)$ & 1430 \\
\hline Core coolant velocity $(\mathrm{m} / \mathrm{s})$ & $<2$ \\
\hline Pressure drop across core $(\mathrm{atm})$ & 0.33 \\
\hline Fuel cycle type & $\begin{array}{l}\text { Low-enrichment uranium-twin core with off-line fuel } \\
\text { assembly shuffling }\end{array}$ \\
\hline $\begin{array}{l}\text { Fuel temperature reactivity coefficient (pcm-[beginning } \\
\text { of cycle]) }(\mathrm{pcm} / \mathrm{K})\end{array}$ & -2.6 \\
\hline Average discharge burnup (GWd/THM) & 68.7 \\
\hline \multicolumn{2}{|c|}{ 6. Coolant and Thermal Performance } \\
\hline Primary coolant & $2^{7} \mathrm{LiF}-\mathrm{BeF}_{2}$ \\
\hline
\end{tabular}




\section{APPENDIX A - REACTOR CONCEPT DESCRIPTION SUMMARY TABLE Small Modular Advanced High-Temperature Reactor-Carbonate Thermochemical Cycle}

\begin{tabular}{|c|c|}
\hline Lithium-7 enrichment & $99.995 \mathrm{wt} \%$ \\
\hline Core inlet/outlet temperature $\left({ }^{\circ} \mathrm{C}\right)$ & $670 / 700$ \\
\hline Primary coolant margin to boiling $(\mathrm{K})$ & $>700 \mathrm{~K}$ \\
\hline Primary coolant redox control & Beryllium contacting \\
\hline Fuel leak and coolant impurity control & $\mathrm{Bi}(\mathrm{Li})$ reductive extraction \\
\hline Primary coolant flow rate $(\mathrm{kg} / \mathrm{s})$ & 1,750 \\
\hline Intermediate coolant flow rate $(\mathrm{kg} / \mathrm{s})$ & 3,970 \\
\hline \multicolumn{2}{|c|}{ 7. Fuel Properties } \\
\hline Fuel type & Uranium oxycarbide TRISO \\
\hline Fuel format & Plate assemblies \\
\hline Number of fuel assemblies & 19 (single cartridge core) \\
\hline Uranium enrichment (wt \%) & 8 \\
\hline Fuel failure temperature & $>1600^{\circ} \mathrm{C}$ \\
\hline $\begin{array}{l}\text { Peak fuel temperature in hottest plate-normal } \\
\text { operations }\left({ }^{\circ} \mathrm{C}\right)\end{array}$ & 902 \\
\hline Peak fuel temperature in average plate $\left({ }^{\circ} \mathrm{C}\right)$ & 805 \\
\hline Fuel doppler coefficient $(\mathrm{pcm} / \mathrm{K})$ & -2.6 \\
\hline Primary coolant temperature coefficient $(\mathrm{pcm} / \mathrm{K})$ & -0.3 \\
\hline Fissile mass (start of equilibrium cycle) $(\mathrm{kg})$ & 96.1 \\
\hline \multicolumn{2}{|c|}{ 8. Refueling Systems } \\
\hline Core format & Cartridge \\
\hline Refueling time (hours) & 8 \\
\hline Core fuel load (MTHM) & 1.9 \\
\hline \multicolumn{2}{|c|}{ 9. Safety Systems } \\
\hline Time before active safety systems required & Infinite \\
\hline Time before human intervention required & Infinite \\
\hline Primary reactivity control trigger & $\begin{array}{l}\text { Melt point links in control blade linkages or loss of power } \\
\text { to engagement mechanism to control blade drive motors }\end{array}$ \\
\hline Secondary shutdown trigger & Melt point link in poison accumulator cover \\
\hline \multicolumn{2}{|c|}{ 10. Containment System } \\
\hline Primary containment boundary & Primary coolant loop and upper gas plenum \\
\hline Source term reduction mechanisms & $\begin{array}{l}\text { Fission product dissolution in primary coolant, } \mathrm{SiC} \text { layer } \\
\text { in fuel particle, core carbon materials }\end{array}$ \\
\hline Secondary containments & $\begin{array}{l}\text { Low-pressure below grade shell; also contains tritium and } \\
\text { beryllium }\end{array}$ \\
\hline Tertiary containment & Flood seal \\
\hline \multicolumn{2}{|c|}{ 11. Decay Heat Management } \\
\hline Normal decay heat removal path & Intermediate loop \\
\hline Safety grade heat removal path & $\begin{array}{l}\text { Three natural circulation driven direct reactor auxiliary } \\
\text { cooling systems }\end{array}$ \\
\hline Safety grade heat removal capacity & $3 \times 0.5 \%$ full power ( 2 out of 3 necessary) \\
\hline Ultimate heat sink & Outside air \\
\hline Used fuel pool safety cooling & Passive tube-contained air loops \\
\hline
\end{tabular}




\section{ATTACHMENT B-ADVANCED NUCLEAR TECHNOLOGY CRITERIA WORKSHEET Small Modular Advanced High-Temperature Reactor-Carbonate Thermochemical Cycle}

\begin{tabular}{|l|}
\hline Information Requested \\
\hline Category I-Safety \\
\hline 1) Describe design features that \\
address defense-in-depth, accident \\
prevention, accident mitigation, and \\
emergency planning.
\end{tabular}

Defense-in-depth: Small modular Advanced High-Temperature Reactor (SmAHTR) has multiple radionuclide containment layers, additional radionuclide retention mechanisms, diverse means to insert negative reactivity, and diverse means to provide decay heat removal. SmAHTR's containment layers include (1) $\mathrm{SiC}$ layer in tri-structural isotropic (TRISO) fuel, (2) the primary coolant boundary, (3) the beryllium and tritium containment layer, and (4) flood containment. SmAHTR's potential source term would also be significantly reduced by dissolution of the radiologically significant fission products and actinides within the primary coolant. Adequate negative reactivity to bring the plant to shutdown can be added by either the primary control blades or reserve poison salt injection systems. Each of the shutdown mechanisms has diverse activation mechanisms. Also, each shutdown mechanism includes at least one passive activation mechanism that cannot be disabled. Core decay heat can be removed using either the normal power cycle or the direct reactor auxiliary cooling system (DRACS). Only two of the three DRACS units are required to accommodate a station blackout event. The used fuel pool also has diverse cooling (a multitube, two-phase, liquid-metal thermosyphon type passive cooling system) or pumped loop.

Accident prevention: SmAHTR avoids pipe break-type loss of coolant accidents through its integral design. SmAHTR also avoids the potential for control blade ejection accidents due to its low-pressure primary system. SmAHTR has over $700 \mathrm{~K}$ of margin to primary coolant boiling, and the core structural elements have even larger margins to component failure.

SmAHTR's moderate core power density provides a large margin to critical heat flux limits. The fuel also has $\sim 700 \mathrm{~K}$ margin to fuel damage. SmAHTR also employs a moderate primary coolant velocity $(<2 \mathrm{~m} / \mathrm{s})$ to minimize any potential fluid-structure interactions. SmAHTR's transparent, single-phase coolant enables providing the plant operators visual observation of the core, including while in operation, enabling high confidence of seeing any plant accidents prior to escalation. SmAHTR is situated below grade to avoid vulnerability to external missiles and includes flood containment to avoid vulnerability to tsunamis or other flooding events.

Accident mitigation: SmAHTR has large thermal inertia due to the large amount of coolant above the core and does not have any identified accident threshold phenomena (e.g., control rod ejection accidents or departure from nucleate boiling). Even gross failure of the first containment layer ( $\mathrm{SiC}$ layer in TRISO) would not result in a large radionuclide release due to the multiple remaining containment layers and source term reduction mechanisms. Employing a guard vessel minimizes the safety impact of primary vessel failure. The low primary system pressure avoids developing a driving force for radionuclide dispersal in the event of a primary coolant boundary failure. Moreover, the radionuclide retention properties of the primary coolant and fuel structural materials markedly reduces the potential source term as does the smaller amount (as compared to an LWR) of the fuel within the core. Emergency planning: SmAHTR reduces the emergency planning requirements largely through a reduced source term, which minimizes the radionuclide plume potential. The reduced potential source term is characteristic of the reactor class due to strong inherent and engineered passive safety characteristics. 


\section{ATTACHMENT B -ADVANCED NUCLEAR TECHNOLOGY CRITERIA WORKSHEET Small Modular Advanced High-Temperature Reactor-Carbonate Thermochemical Cycle}

\begin{tabular}{|c|c|}
\hline Information Requested & Concept Description \\
\hline $\begin{array}{l}\text { 2) Provide sufficient design } \\
\text { information on the shutdown and } \\
\text { decay heat removal systems to } \\
\text { allow an assessment of their } \\
\text { effectiveness and reliability. }\end{array}$ & 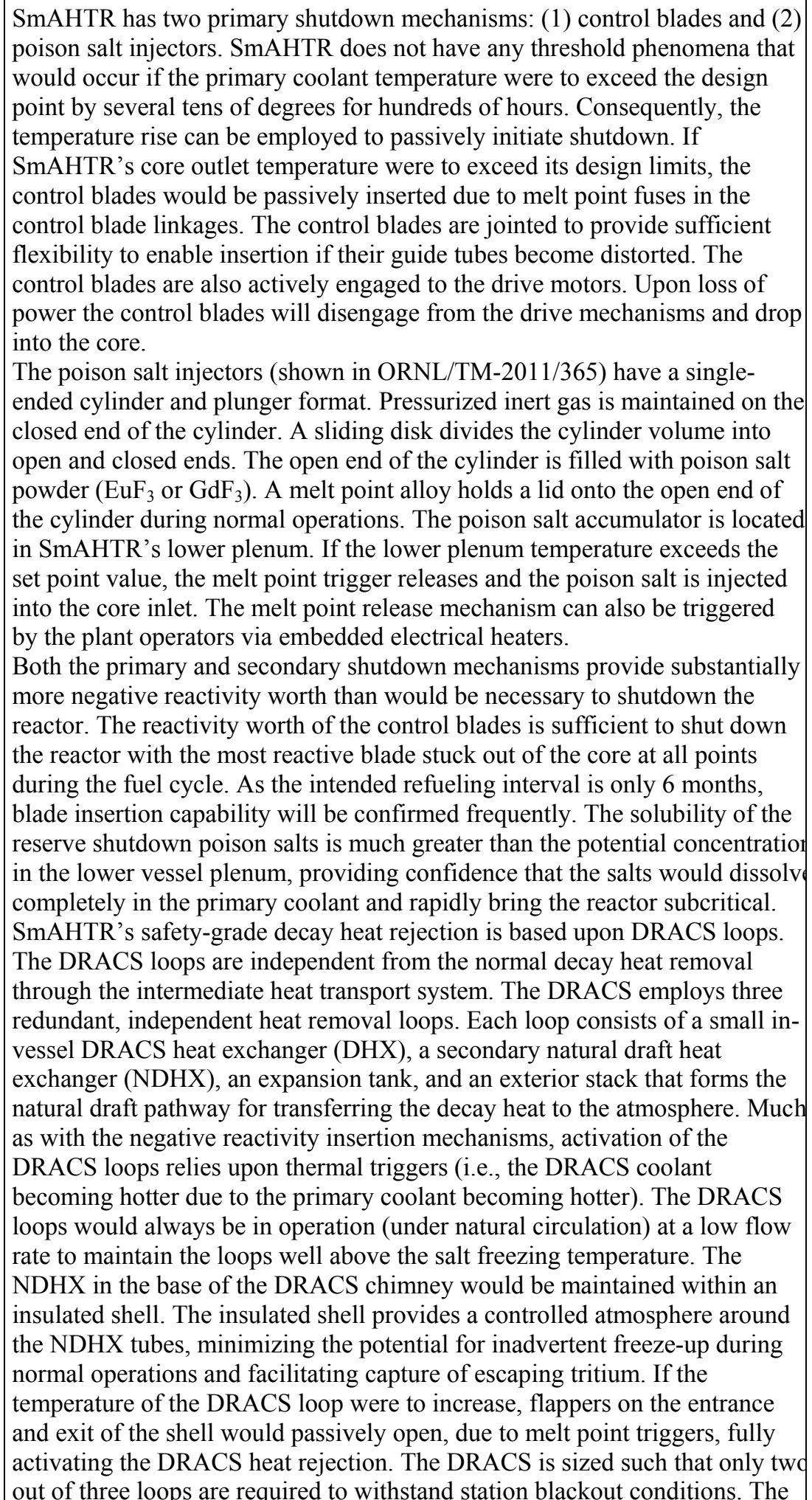 \\
\hline
\end{tabular}




\section{ATTACHMENT B-ADVANCED NUCLEAR TECHNOLOGY CRITERIA WORKSHEET Small Modular Advanced High-Temperature Reactor-Carbonate Thermochemical Cycle}

\begin{tabular}{|c|c|}
\hline Information Requested & Concept Description \\
\hline & $\begin{array}{l}\text { plant operators can also manually open the NDHX flaps, providing a diverse } \\
\text { back-up activation method. The large plant thermal inertia provides hours } \\
\text { before lack of decay heat removal would damage the primary coolant } \\
\text { boundary. } \\
\text { None of the passive activation mechanisms can be disabled by the plant } \\
\text { operators, minimizing the potential safety impact of operator error or } \\
\text { sabotage. }\end{array}$ \\
\hline $\begin{array}{l}\text { 3) Describe the expected response } \\
\text { of the concept to normal and } \\
\text { abnormal conditions. For example, } \\
\text { describe the concept design and } \\
\text { associated instrumentation that will } \\
\text { provide operators with longer times } \\
\text { than for current generation light } \\
\text { water reactors (LWRs) for system } \\
\text { diagnosis of slowly evolving } \\
\text { accidents before reaching safety } \\
\text { systems activation and/or exposure } \\
\text { of vital equipment to adverse } \\
\text { conditions. }\end{array}$ & $\begin{array}{l}\text { SmAHTR's intended response to any significantly abnormal conditions is to } \\
\text { shutdown and assess the situation before resuming operation. Passive, natura } \\
\text { circulation driven decay heat removal backs up the normal core heat removal } \\
\text { systems. SmAHTR has much larger thermal margins to fuel failure or } \\
\text { primary coolant boundary failure than are available in LWRs. SmAHTR has } \\
\text { a large, inert gas filled upper plenum minimizing the potential to } \\
\text { inadvertently pressurize the reactor vessel. The much larger margins to fuel } \\
\text { or vessel failure combined with the large system thermal inertia and lower } \\
\text { core power density combine to provide ample time for operator response to } \\
\text { any unforeseen circumstances. } \\
\text { SmAHTR's low-pressure transparent coolant facilitates direct visual } \\
\text { observation of in-vessel conditions. Observing that the core is intact, the } \\
\text { coolant level is correct, the reactor vessel is intact, and that the flow passages } \\
\text { within the core are unobstructed provide the operators high confidence that } \\
\text { the reactor is operating normally. If the core temperature were to increase, its } \\
\text { visual emissions (brighter red glow) would also increase, providing early } \\
\text { indication of improper operation. Visual observation is based upon multiple } \\
\text { cameras located above the reactor vessel that are optically coupled through } \\
\text { free space via windows located in standpipes above the upper vessel. The } \\
\text { same viewports would provide direct observation of the reactor vessel } \\
\text { condition, providing early observation of vessel creep. Significant corrosion } \\
\text { of the primary containment would also be detected through visual } \\
\text { observation. Chromium is the most corrosion-vulnerable component of the } \\
\text { reactor vessel. Chromium fluoride is green. Monitoring the otherwise } \\
\text { transparent primary coolant's optical absorption would thus provide early } \\
\text { indication of vessel damage. }\end{array}$ \\
\hline $\begin{array}{l}\text { 4) Describe the design features } \\
\text { that will reduce the probability for } \\
\text { accidents, including accidents with } \\
\text { potentially severe consequences. } \\
\text { These design features should } \\
\text { provide sufficient reliability, } \\
\text { redundancy, diversity, and } \\
\text { independence in safety systems to } \\
\text { provide for either accident } \\
\text { prevention or accident mitigation. }\end{array}$ & $\begin{array}{l}\text { Fluoride salt-cooled high temperature reactors (FHRs) employ TRISO fuel. } \\
\text { TRISO fuel has high tolerance for thermal excursions, reducing the } \\
\text { probability for fuel damage accidents. The in-vessel structural materials } \\
\text { (continuous fiber ceramic composites [CFCCs]) also have large thermal } \\
\text { margins to failure. The large primary coolant heat capacity with the lower } \\
\text { core power density combine to lower the flow velocity and pressure drop } \\
\text { across the core, reducing the flow-induced mechanical stresses on the fuel. } \\
\text { SmAHTR employs an integral primary system configuration, avoiding the } \\
\text { potential for major pipe break loss of coolant-type accidents. SmAHTR's } \\
\text { high coolant melting point would result in auto-plugging of small vessel } \\
\text { leaks, preventing large loss of coolant accidents from the reactor vessel. } \\
\text { TRISO fuel has a strong negative Doppler reactivity feedback with a large } \\
\text { margin to fuel damage, inherently reducing the consequences of inadvertent } \\
\text { reactivity insertion accidents. SmAHTR also has a large thermal inertia, } \\
\text { providing extended time for accident mitigation responses. The fluoride salt } \\
\text { coolant does not chemically react energetically with environmental } \\
\text { materials (e.g., water). SmAHTR-carbonate thermochemical cycle's } \\
\text { (CTC's) nuclear island will not include significant volumes of water, }\end{array}$ \\
\hline
\end{tabular}




\section{ATTACHMENT B-ADVANCED NUCLEAR TECHNOLOGY CRITERIA WORKSHEET Small Modular Advanced High-Temperature Reactor-Carbonate Thermochemical Cycle}

\begin{tabular}{|c|c|}
\hline Information Requested & Concept Description \\
\hline & $\begin{array}{l}\text { avoiding the potential for steam explosion-type accidents. The primary and } \\
\text { intermediate coolants are at atmospheric pressure. Consequently, no driving } \\
\text { force exists to disperse radionuclides in the event of an accident. SmAHTR } \\
\text { employs a large inert gas upper plenum to prevent primary system pressure } \\
\text { shocks. The reactor vessel can withstand temperature excursions of tens of } \\
\text { degrees for hundreds of hours, providing high confidence that the vessel will } \\
\text { not rapidly develop an unanticipated leak. }\end{array}$ \\
\hline $\begin{array}{l}\text { 5) Describe the design features } \\
\text { that will minimize potential } \\
\text { radiation exposures to plant } \\
\text { personnel. }\end{array}$ & $\begin{array}{l}\text { FLiBe has minimal long-term activation (longest half-life is } 27 \mathrm{~s} \text { from }{ }^{19} \mathrm{O} \text { ). } \\
\text { No plant staff will enter containment while the plant is in operation or for } \\
\text { several minutes after shutdown. SmAHTR employs an integral design that } \\
\text { keeps the primary coolant within the reactor vessel. The primary coolant } \\
\text { cleanup system is designed to reduce any circulating activity from leaking } \\
\text { fuel or corrosion product activation to acceptable levels. SmAHTR will } \\
\text { employ remote operations and telepresence-based maintenance and } \\
\text { refueling to a much greater degree than current generation LWRs. The } \\
\text { pervasive networking required to support telepresence is facilitated by } \\
\text { SmAHTR's low-pressure containment, which significantly decreases the } \\
\text { difficulty of networking penetrations. }\end{array}$ \\
\hline $\begin{array}{l}\text { 6) Describe how incorporation of } \\
\text { defense-in-depth philosophy is } \\
\text { accomplished in the concept design. } \\
\text { Specifically, describe how the } \\
\text { multiple barriers are maintained to } \\
\text { prevent radiation release, and thereby } \\
\text { reduce the consequences of severe } \\
\text { accidents. }\end{array}$ & $\begin{array}{l}\text { SmAHTR features multiple, independent radionuclide containment boundaries } \\
\text { and source term reduction mechanisms. TRISO fuel features an inner SiC } \\
\text { containment layer. Both the fuel particles and the surrounding carbon material } \\
\text { also would retain radionuclides in the event of failed or defective } \mathrm{SiC} \\
\text { containment. The primary salt coolant would also dissolve and chemically bind } \\
\text { all but the noble radionuclides. The noble metals will either plate out onto } \\
\text { primary coolant wetted surfaces or remain suspended as colloids in the coolant } \\
\text { salt with no tendency to form aerosols. Molten salt reactors have provided } \\
\text { strong evidence of the retention properties of radionuclides in the primary } \\
\text { coolant. The primary coolant boundary is the next radionuclide containment } \\
\text { layer. The beryllium and tritium containment layer is outside of the primary } \\
\text { coolant system. The flood containment layer provides an additional radionuclide } \\
\text { barrier. None of the containment layers includes large volumes of water or other } \\
\text { material whose phase change might pressurize the containments. The reactor is } \\
\text { located below grade to provide shielding from external missiles. The } \\
\text { intermediate coolant loop is above the in-vessel heat exchanger, ensuring that } \\
\text { heat exchanger tube leaks would be inwards. }\end{array}$ \\
\hline $\begin{array}{l}\text { 7) Describe the features that could } \\
\text { result in a large release of } \\
\text { radioactive materials, such as those } \\
\text { that would prevent a simultaneous } \\
\text { loss of containment integrity } \\
\text { (including situations where the } \\
\text { containment is by-passed), and the } \\
\text { ability to maintain core cooling as a } \\
\text { result of an aircraft impact. If } \\
\text { prevention of release is not possible } \\
\text { under this scenario, identify system } \\
\text { designs that would provide a delay } \\
\text { in radiological releases to facilitate } \\
\text { any required emergency response } \\
\text { both on-site and off-site. }\end{array}$ & $\begin{array}{l}\text { SmAHTR has no evaluated accidents (e.g., those with nontrivial } \\
\text { probabilities) that would result in a large release of radioactive materials. } \\
\text { The reactor is located below grade to minimize the potential for direct } \\
\text { aircraft impact. Decay heat removal is provided first by the power cycle } \\
\text { whose heat rejection mechanisms are located 100+ meters from the reactor. } \\
\text { Three spatially separated, mechanically robust DRACS chimneys provide } \\
\text { decay heat removal in the event that the normal heat transfer mechanism is } \\
\text { unavailable. In the event of multiple aircraft impacts disabling multiple } \\
\text { DRACS towers and the primary heat rejection path, the large plant thermal } \\
\text { inertia provides many hours for the plant staff to clear the rubble and begin } \\
\text { emergency cooling. }\end{array}$ \\
\hline
\end{tabular}




\section{ATTACHMENT B-ADVANCED NUCLEAR TECHNOLOGY CRITERIA WORKSHEET Small Modular Advanced High-Temperature Reactor-Carbonate Thermochemical Cycle}

\begin{tabular}{|c|c|}
\hline Information Requested & Concept Description \\
\hline $\begin{array}{l}\text { 8) Describe the features that will } \\
\text { prevent loss of onsite spent fuel } \\
\text { storage capability and facility } \\
\text { integrity (if part of the concept } \\
\text { design), including consideration of } \\
\text { an aircraft impact and other external } \\
\text { events. }\end{array}$ & $\begin{array}{l}\text { Used fuel will be stored below grade in a FLiBe filled pool within } \\
\text { containment for 6-12 months. The used fuel pool has both a primary and } \\
\text { diverse cooling system. The diverse cooling system employs a multi-tube, } \\
\text { liquid-metal thermosyphon-type passive cooling. The normal and diverse } \\
\text { cooling systems have independent and spatially separated heat sinks. } \\
\text { After 6-12 months (enabled by the lower core power density and fuel } \\
\text { robustness), the fuel assemblies will be transferred to indefinite-term, on- } \\
\text { site dry well storage. Neither TRISO nor carbon is water soluble, providing } \\
\text { high confidence the used fuel will not leak radionuclides into the } \\
\text { environment. Further, the TRISO SiC barrier remains with the fuel and is } \\
\text { unlikely to fail in the comparatively benign environment of below-grade } \\
\text { dry-well storage. }\end{array}$ \\
\hline $\begin{array}{l}\text { 9) Identify any R\&D that would be } \\
\text { needed to bring any of the safety- } \\
\text { related technologies used in the } \\
\text { design to a sufficient level of } \\
\text { maturity to allow for industrial use. }\end{array}$ & $\begin{array}{l}\text { FHRs are just entering into early phase engineering development. A number } \\
\text { of important safety demonstrations remain. The recently published FHR } \\
\text { Technology Development Roadmap (ORNL/TM-2013/401) provides a } \\
\text { listing of the initial set of demonstrations. Key demonstrations that remain } \\
\text { to be performed are (1) DRACS performance, (2) safety evaluation } \\
\text { methodology and toolset, (3) melt point fuses, (4) reactor structural material } \\
\text { qualification, (5) instrumentation system, (6) fuel qualification, and (7) } \\
\text { control blade mechanical performance. Overall, substantial RD\&D remains } \\
\text { before FHRs are sufficiently mature to enter into commercial service. }\end{array}$ \\
\hline \multicolumn{2}{|l|}{ Category II-Security } \\
\hline $\begin{array}{l}\text { 1) Types of special nuclear } \\
\text { materials (SNM) present and the } \\
\text { security features that provide SNM } \\
\text { protection. }\end{array}$ & $\begin{array}{l}\text { SmAHTR-CTC will employ TRISO fuel. The fuel onsite can be classified in } \\
\text { four ways: } \\
\text { 1. Fresh fuel onsite for loading-This fuel will be uranium enriched } \\
\text { to } 8 \% \text { U-235. The operational aspects of reloading the SmAHTR } \\
\text { have not been fully established yet. However, the team will involve } \\
\text { security specialists in the design of this process to make certain that } \\
\text { procedures are in place that ensure the security of the fresh fuel } \\
\text { throughout the delivery and reloading process. } \\
\text { 2. Reactor core-This fuel is being used actively in the core. As with } \\
\text { other reactors, the composition of this fuel will change over the } \\
\text { lifetime of the core. U-235 concentration will decrease and } \\
\text { plutonium concentration will increase over time. The reactor core } \\
\text { will be located below grade. This will make access to the core } \\
\text { more difficult for would-be saboteurs and provide added protection } \\
\text { for certain attack scenarios, such as aircraft impact and missile } \\
\text { launching from off-site locations. } \\
\text { 3. Used fuel in used fuel pool-Fuel that is removed from the core } \\
\text { will be initially stored in an underground FLiBe pool for a period } \\
\text { of } 6-12 \text { months to allow it to cool to a point where it can safely } \\
\text { exist outside the cooling environment of FLiBe. The used fuel pool } \\
\text { will be located below grade, and the fuel will be highly } \\
\text { radioactive-and therefore, highly self-shielding - during the } 6-12 \\
\text { months that it will be stored in the used fuel pool. } \\
\text { 4. Used fuel in dry well storage-After the fuel has sufficiently } \\
\text { cooled, it will be transferred to on-site dry-well storage. The fuel in } \\
\text { dry well storage will be difficult to obtain since it will be encased } \\
\text { and cemented in boreholes and monitored closely by security } \\
\text { personnel. }\end{array}$ \\
\hline
\end{tabular}




\section{ATTACHMENT B-ADVANCED NUCLEAR TECHNOLOGY CRITERIA WORKSHEET Small Modular Advanced High-Temperature Reactor-Carbonate Thermochemical Cycle}

\begin{tabular}{|c|c|}
\hline Information Requested & Concept Description \\
\hline & $\begin{array}{l}\text { Since the operational aspects of the SmAHTR have not been fully } \\
\text { developed, there will be more details on how the different SNM types will } \\
\text { be protected. As the design of the SmAHTR progresses, the physical } \\
\text { protection system (PPS) will be developed along with details of the } \\
\text { operational and safety aspects of the plant. This will ensure that the SNM } \\
\text { will be more than adequately protected. }\end{array}$ \\
\hline $\begin{array}{l}\text { 2) Consideration of security } \\
\text { requirements together throughout the } \\
\text { design process so that security issues } \\
\text { (e.g., threats of theft, diversion, and } \\
\text { sabotage) can be effectively } \\
\text { anticipated, identified, and addressed } \\
\text { at an early stage through integrated } \\
\text { facility design and engineered } \\
\text { security features, and through } \\
\text { formulation of response/mitigation } \\
\text { measures, ideally with reduced } \\
\text { reliance on human actions compared } \\
\text { with previous generations. }\end{array}$ & $\begin{array}{l}\text { SmAHTR is in an early stage of engineering development. As such, no } \\
\text { explicit PPS has been designed. However, it is expected that security experts } \\
\text { will be made an integral part of the design/engineering team to ensure that } \\
\text { security-by-design is implemented throughout the process in the future. } \\
\text { Theft and sabotage scenarios will be considered. Regulatory requirements } \\
\text { will be met or exceeded. Hardening of components and systems against both } \\
\text { theft and sabotage will be accomplished via a process of interacting with } \\
\text { safety system designers. All aspects of plant design and operation will be } \\
\text { considered during the development of the PPS. Cost-benefit analysis for } \\
\text { design improvements will be included in any scenario analysis. Mitigation } \\
\text { of the effects of any potential security events will be considered as part of } \\
\text { the PPS design process. } \\
\text { Diversion possibilities will be minimized via the use of a transparency } \\
\text { process that will ensure regulators have up-to-date information. Information } \\
\text { from operations, safety, and security will be shared with safeguards } \\
\text { personnel and with the appropriate regulatory authorities to ensure that; } \\
\text { overall, a transparent system is in place. }\end{array}$ \\
\hline $\begin{array}{l}\text { 3) Features to prevent/mitigate } \\
\text { sabotage threats, for example, loss of } \\
\text { integrity of onsite core fuel and spent } \\
\text { fuel storage, including consideration } \\
\text { of an aircraft impact and other } \\
\text { relevant attack scenarios. }\end{array}$ & $\begin{array}{l}\text { Both the reactor and the used fuel pool are located underground, which } \\
\text { makes access to the fuel difficult to achieve. After the used fuel is removed } \\
\text { from the used fuel pool, it is placed in an encased, cemented borehole and } \\
\text { monitored by security personnel. } \\
\text { Other aspects of the PPS will be developed throughout the design process of } \\
\text { the plant and will include security experts to ensure the protection of any } \\
\text { onsite fuel. }\end{array}$ \\
\hline $\begin{array}{l}\text { 4) Features to eliminate or reduce } \\
\text { the potential theft of nuclear } \\
\text { material. }\end{array}$ & $\begin{array}{l}\text { Both the reactor and the used fuel pool are located underground, which } \\
\text { makes access to the fuel difficult to achieve. After the used fuel is removed } \\
\text { from the used fuel pool, it is placed in an encased, cemented borehole and } \\
\text { monitored by security personnel. } \\
\text { Other aspects of the PPS will be developed throughout the design process of } \\
\text { the plant and will include security experts to ensure the protection of any } \\
\text { onsite fuel. }\end{array}$ \\
\hline $\begin{array}{l}\text { 5) Any features that will require } \\
\text { R\&D to bring to maturity. }\end{array}$ & \\
\hline \multicolumn{2}{|c|}{ Category III-Ability to improve uranium resource utilization and minimize waste generation } \\
\hline $\begin{array}{l}\text { 1) Uranium resource utilization: } \\
\text { a) Uranium enrichment required } \\
\text { (compared to existing LWR } \\
\text { systems) } \\
\text { b) Design features, if any, that } \\
\text { reduce uranium consumption } \\
\text { c) Is the use of reprocessed fuel } \\
\text { planned for the concept system } \\
\text { in its fuel cycle? }\end{array}$ & $\begin{array}{l}\text { SmAHTR is a thermal spectrum reactor that employs carbon as its primary } \\
\text { moderator material. SmAHTR will have slightly improved uranium } \\
\text { resource utilization as compared to small-sized LWRs (discharge burnup } \\
\sim 68.7 \text { GWd/MTU). SmAHTR's large surface-to-volume ratio, as compared } \\
\text { to large reactors, results in a higher neutron leakage fraction. However, } \\
\text { carbon has lower neutron absorption than light water, improving neutron } \\
\text { utilization. SmAHTR's lower core fuel loading as compared to LWRs } \\
\text { necessitates (in order to achieve an acceptable refueling interval) higher } \\
(8 \mathrm{wt} \%) \text { uranium enrichment. SmAHTR's robust fuel and coolant enables }\end{array}$ \\
\hline
\end{tabular}




\section{ATTACHMENT B-ADVANCED NUCLEAR TECHNOLOGY CRITERIA WORKSHEET Small Modular Advanced High-Temperature Reactor-Carbonate Thermochemical Cycle}

\begin{tabular}{|c|c|}
\hline Information Requested & Concept Description \\
\hline $\begin{array}{l}\text { d) What is the expected } \\
\text { conversion ratio for the } \\
\text { proposed concept design? Can } \\
\text { the concept system be used for } \\
\text { fissile material breeding? } \\
\text { e) What are the R\&D needs? }\end{array}$ & $\begin{array}{l}\text { the core to tolerate arbitrary power distribution, avoiding the need for } \\
\text { burnable poisons. SmAHTR employs a dual-core concept wherein three of } \\
\text { the } 19 \text { fuel assemblies ( } 38 \text { in the two cores) are replaced every } 6 \text { months, } \\
\text { increasing the average discharge burnup through fuel shuffling. SmAHTR's } \\
\text { core needs to be lifted from the vessel as a single object. The core's carbon } \\
\text { materials are closely fitted together to maximize neutronic efficiency. } \\
\text { Radiation-induced mechanical distortion will occur in use, effectively } \\
\text { preventing separately removing individual fuel assemblies. TRISO has been } \\
\text { demonstrated with plutonium and other actinides as the fissile material. } \\
\text { Consequently, SmAHTR could use reprocessed fuel. However, the use of } \\
\text { reprocessed fuel is not currently being considered for the baseline design. } \\
\text { SmAHTR will have a conversion ratio below } 1.0 \text { and hence is not suitable } \\
\text { for fissile material breeding. SmAHTR's uranium resource utilization could } \\
\text { be improved by further core design optimization. However, as a thermal } \\
\text { spectrum, low-enriched uranium (LEU) reactor, reasonable confidence is } \\
\text { already available on the likely potential range of uranium requirements. }\end{array}$ \\
\hline $\begin{array}{l}\text { 2) Estimate of used fuel/waste } \\
\text { generation (qualitatively compared } \\
\text { to a once-through LWR). } \\
\text { a) Ability to transmute long- } \\
\text { lived products in spent fuel; } \\
\text { those produced in situ during } \\
\text { reactor operation. } \\
\text { b) Mass (qualitatively compared } \\
\text { to an LWR discharge) of high } \\
\text { longevity/high heat materials } \\
\text { (example transuranics) requiring } \\
\text { long-term geologic isolation. } \\
\text { c) Mass (qualitatively compared } \\
\text { to an LWR discharge) of low } \\
\text { heat, long-lived materials } \\
\text { (examples carbon-14, } \\
\text { technetium-99, iodine-129). } \\
\text { d) Mass (qualitatively compared } \\
\text { to an LWR discharge) of low } \\
\text { heat, low longevity materials } \\
\text { (Class A, B, C low-level waste } \\
\text { (LLW). } \\
\text { e) R\&D needs to facilitate } \\
\text { transmutation or other waste } \\
\text { management goals. }\end{array}$ & $\begin{array}{l}\text { SmAHTR will generate slightly less used fuel on a heavy metal and fission } \\
\text { product mass basis than small-sized LWRs, but more on a volume basis due } \\
\text { to the inclusion of some of the moderator material along with the TRISO } \\
\text { particles in the fuel assemblies. SmAHTR employs moderation both within } \\
\text { individual fuel assemblies and between fuel assemblies. } \\
\text { a) SmAHTR is a solid fuel, thermal spectrum reactor and has not been } \\
\text { considered for a minor actinide disposition mission. } \\
\text { b) SmAHTR's slightly improved uranium utilization than small-sized } \\
\text { LWRs will result in a slightly smaller mass of high-level waste relative } \\
\text { to a small sized LWRs. } \\
\text { c) SmAHTR will generate significantly more low-heat, long-lived } \\
\text { radioactive materials (e.g., carbon-14) than an LWR. A carbon material } \\
\text { recycle strategy would need to be developed to significantly decrease } \\
\text { the amount of low activity carbon. } \\
\text { d) A low level waste estimate is not yet available for SmAHTR. } \\
\text { SmAHTR's design would have to be fundamentally changed (primarily } \\
\text { by removing the carbon moderator) to achieve a significantly harder } \\
\text { neutron spectrum and thereby support waste transmutation goals. } \\
\text { e) R\&D on carbon recycling and mechanical stripping of TRISO particles } \\
\text { from carbon bodies would, if successful, result in substantially reduce } \\
\text { SmAHTR's net discharge of carbon-14 and decrease the volume of low- } \\
\text { heat, long-lived waste generated. }\end{array}$ \\
\hline \multicolumn{2}{|c|}{$\begin{array}{l}\text { Category IV-Operational capabilities and aspects such as control strategies, operating modes (e.g., base load } \\
\text { vs load following capability), maintenance and inspection requirements, refueling interval, etc. }\end{array}$} \\
\hline $\begin{array}{l}\text { 1) Electricity generation } \\
\text { capabilities, including flexibility in } \\
\text { electricity generation including the } \\
\text { proposed concept's capability for } \\
\text { load following (the capability to } \\
\text { adjust generation as demand for } \\
\text { electricity fluctuates). Limitations, }\end{array}$ & $\begin{array}{l}\text { SmAHTR-CTC is focused on hydrogen production instead of electricity } \\
\text { generation. SmAHTR could be connected to a high-efficiency electricity } \\
\text { generation cycle. SmAHTR's high degree of passive safety and robust fuel } \\
\text { and materials would enable comparatively rapid power level shifts (i.e., } \\
\text { TRISO is not vulnerable to pellet-clad interaction). }\end{array}$ \\
\hline
\end{tabular}




\section{ATTACHMENT B-ADVANCED NUCLEAR TECHNOLOGY CRITERIA WORKSHEET Small Modular Advanced High-Temperature Reactor-Carbonate Thermochemical Cycle}

\begin{tabular}{|c|c|}
\hline Information Requested & Concept Description \\
\hline $\begin{array}{l}\text { if any, on such operation arising } \\
\text { from considerations of fuel } \\
\text { performance, reactivity limitations, } \\
\text { mechanical and thermal stress in } \\
\text { materials and components should be } \\
\text { addressed. }\end{array}$ & \\
\hline $\begin{array}{l}\text { 2) Other features allowing } \\
\text { utilization beyond base-load } \\
\text { electricity production, for example } \\
\text { process heat generation, high- } \\
\text { temperature operation for hydrogen } \\
\text { production via chemical splitting, } \\
\text { etc. }\end{array}$ & $\begin{array}{l}\text { SmAHTR-CTC is focused on hydrogen generation. The CTC is especially } \\
\text { well suited for coupling to an FHR as it is thermodynamically efficient, } \\
\text { requires a peak temperature of }<650^{\circ} \mathrm{C} \text {, and does not require any highly } \\
\text { caustic materials. Focusing initially on hydrogen production enables a first } \\
\text { generation plant to avoid direct completion with mature LWR technology by } \\
\text { producing a product that is not well suited for the output characteristics of } \\
\text { LWRs. }\end{array}$ \\
\hline $\begin{array}{l}\text { 3) Features expected to improve } \\
\text { availability in operation as } \\
\text { estimated from the system's } \\
\text { capacity factor, frequency of } \\
\text { outages for refueling, and other } \\
\text { planned outages (compared with } \\
\text { those for an LWR). Include in the } \\
\text { analysis of operational } \\
\text { availability/dependability, elements } \\
\text { from the information requested } \\
\text { under Category V that follows, } \\
\text { which includes concept maturity } \\
\text { and operating experience (if } \\
\text { available) associated with the } \\
\text { proposed concept. }\end{array}$ & 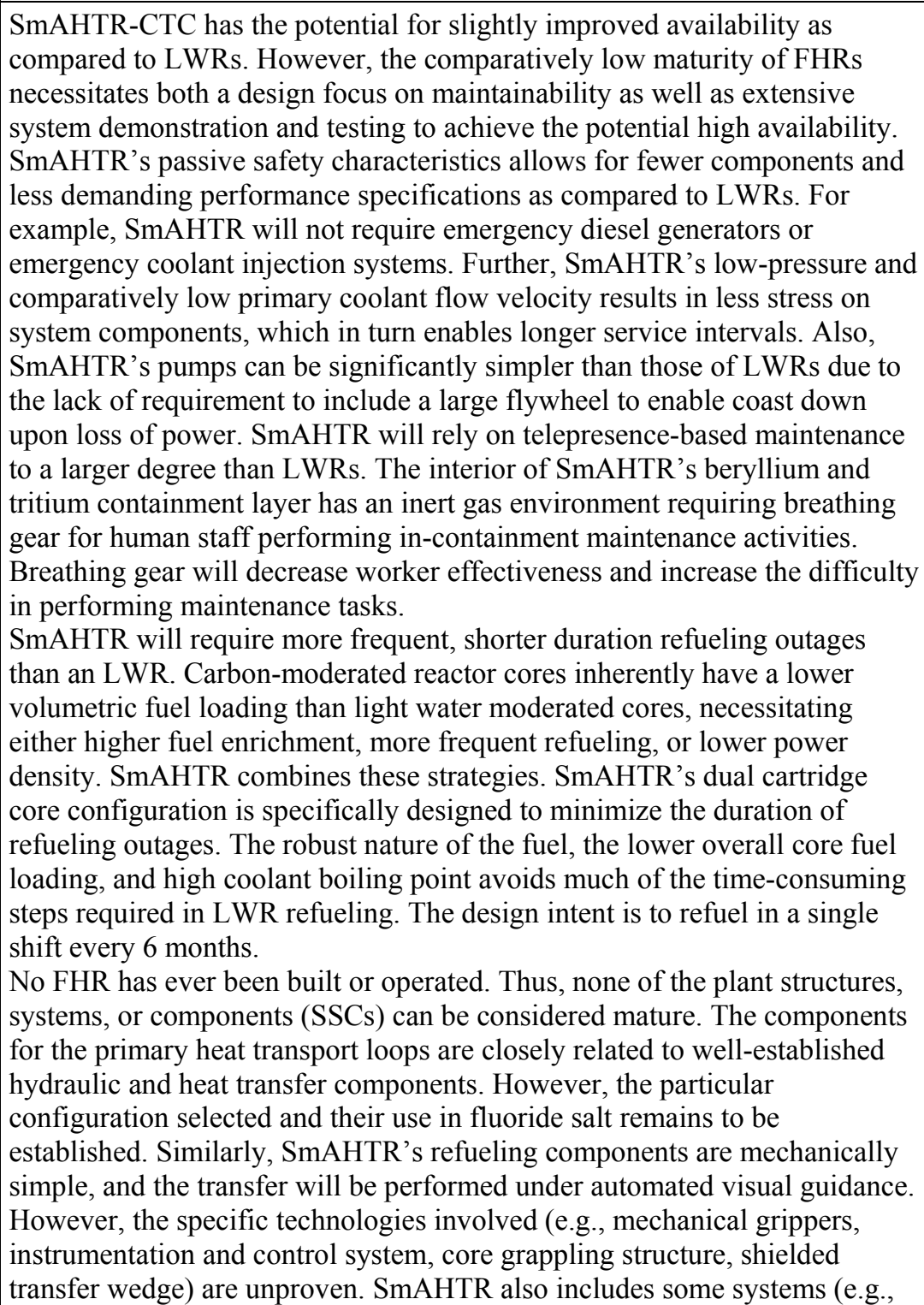 \\
\hline
\end{tabular}




\section{ATTACHMENT B-ADVANCED NUCLEAR TECHNOLOGY CRITERIA WORKSHEET Small Modular Advanced High-Temperature Reactor-Carbonate Thermochemical Cycle}

\begin{tabular}{|c|c|}
\hline ation Requested & Concept Description \\
\hline & $\begin{array}{l}\text { the chemistry control system) that do not have close analogies to proven } \\
\text { industrial technologies and will, consequently, require substantial } \\
\text { development prior to demonstration. Overall, SmAHTR-CTC has the } \\
\text { potential for high availability, but will require an extensive RD\&D effort to } \\
\text { realize the potential. }\end{array}$ \\
\hline $\begin{array}{l}\text { 4) Maintenance and operation- } \\
\text { Are there features that will allow } \\
\text { easier maintenance to reduce the } \\
\text { duration and frequency of outages? } \\
\text { Are there special requirements for } \\
\text { maintenance and inspection that are } \\
\text { different from current LWRs } \\
\text { (simpler or more complex)? }\end{array}$ & $\begin{array}{l}\text { SmAHTR is a thermal power plant. As such, much of its maintenance } \\
\text { requirements will resemble those of other thermal power plants. Some } \\
\text { aspects of SmAHTR's characteristics will ease the maintenance challenges } \\
\text { (e.g., passive safety, low pressure, and visual access) while others will } \\
\text { increase the difficulty (e.g., high temperature, inert gas containment, lack of } \\
\text { proven hydraulic components such as valves and drain plugs). SmAHTR's } \\
\text { containment atmosphere, in addition to being inert, will be contaminated } \\
\text { with beryllium fluoride. Hence, all in-containment maintenance activities } \\
\text { will need to be performed in breathing gear. } \\
\text { The plant passive safety characteristics will decrease the complexity of the } \\
\text { instrumentation wiring, transferring much of the instrumentation from safety } \\
\text { systems to the plant control system and facilitating the use of modern digital } \\
\text { networking. The plant passive safety will also reduce the amount of cabling } \\
\text { that needs to be fireproofed, which will significantly decrease the } \\
\text { maintenance and replacement challenges. }\end{array}$ \\
\hline $\begin{array}{l}\text { 5) Describe design efforts to } \\
\text { provide reliable equipment in the } \\
\text { balance-of-plant (BOP) (or safety- } \\
\text { system independence from BOP) to } \\
\text { reduce the number of challenges to } \\
\text { safety systems. }\end{array}$ & $\begin{array}{l}\text { SmAHTRs feature a long, low-pressure, intermediate loop whose primary } \\
\text { purpose is to isolate the nuclear island from the BOP. The intermediate loop } \\
\text { includes both bellows and rupture disks to mechanically and physically } \\
\text { isolate the primary system from any disturbances in the BOP. The } \\
\text { intermediate } \mathrm{KF}-\mathrm{ZrF}_{4} \text { coolant does not react strongly with the environment } \\
\text { or BOP processes and chemicals. }\end{array}$ \\
\hline $\begin{array}{l}\text { 6) R\&D needs to achieve reactor } \\
\text { performance goals. }\end{array}$ & $\begin{array}{l}\text { A sustained, substantial RD\&D program will be required to raise the } \\
\text { maturity level of SmAHTR's systems and components sufficiently for } \\
\text { industrial use. The recently published FHR technology development } \\
\text { roadmap (ORNL/TM-2013/401) provides details of the scope and nature of } \\
\text { the required developments and demonstrations. }\end{array}$ \\
\hline \multicolumn{2}{|c|}{ Category V-Concept maturity, operating experience, unknowns, and assumptions } \\
\hline $\begin{array}{l}\text { 1) Description of the general level } \\
\text { of concept design maturity (pre- } \\
\text { conceptual, conceptual, or detailed). } \\
\text { Identify the proposed schedule for } \\
\text { completion of the design, duration of } \\
\text { construction (as a function of } \\
\text { availability of funds, if appropriate), } \\
\text { and initial operation of the proposed } \\
\text { concept. }\end{array}$ & $\begin{array}{l}\text { SmAHTR's design is nearing a pre-conceptual level of maturity. FHRs have } \\
\text { now been in conceptual development for slightly more than a decade. } \\
\text { Technologies have been identified to perform all of the required functions. } \\
\text { However, an integrated system layout that includes all of the required } \\
\text { elements does not yet exist. The CTC also has only been demonstrated at } \\
\text { laboratory scale in discrete steps. All of the identified technology issues are } \\
\text { anticipated to be resolved within a decade with sufficient resources. }\end{array}$ \\
\hline \begin{tabular}{|l|} 
2) Description of Technology \\
Readiness Levels (TRL) (based on \\
DOE TRL definition contained in the \\
DOE G 413.3-4, US Department of \\
Energy Technology Readiness \\
Assessment Guide) of major \\
technologies and systems and their \\
relation to previous operating
\end{tabular} & $\begin{array}{l}\text { SmAHTR-CTC has a wide range of TRLs. As SmAHTR's rely heavily on } \\
\text { adapting proven industrial technologies to a different environment, much of } \\
\text { the plant can be considered relatively mature (TRL 6-8). However, several } \\
\text { key plant technologies have only been demonstrated at laboratory scale and } \\
\text { substantial development remains before they can be considered for } \\
\text { industrial deployment (TRL 3-4). For example, a bismuth-lithium-based } \\
\text { reductive extraction system (intended to remove fission products from } \\
\text { FLiBe) was investigated both theoretically and experimentally by the }\end{array}$ \\
\hline
\end{tabular}




\section{ATTACHMENT B-ADVANCED NUCLEAR TECHNOLOGY CRITERIA WORKSHEET Small Modular Advanced High-Temperature Reactor-Carbonate Thermochemical Cycle}

\begin{tabular}{|c|c|}
\hline Information Requested & Concept Description \\
\hline $\begin{array}{l}\text { reactors. Identify the overall TRL of } \\
\text { the proposed concept, which should } \\
\text { be based on the TRL of the least } \\
\text { ready major technology or system. }\end{array}$ & $\begin{array}{l}\text { molten salt reactor program for several years. However, a configuration } \\
\text { suitable for use in at SmAHTR and appropriate container materials have yet } \\
\text { to be established. Also, }{ }^{7} \mathrm{Li} \text { isotope separation technology was successfully } \\
\text { developed at industrial scale in the } 1950 \text { s. However, the specific technology } \\
\text { employed is no longer environmentally acceptable. Related } \\
\text { (environmentally acceptable) technology has been demonstrated at } \\
\text { laboratory-scale. The TRL of lithium isotope separation thus could be } \\
\text { interpreted to be as high as nine or as low as three. }\end{array}$ \\
\hline $\begin{array}{l}\text { 3) Applicable experience from } \\
\text { other reactor systems (e.g., test, } \\
\text { research, demonstration reactors, } \\
\text { naval reactors, foreign reactors) such } \\
\text { as design elements, component } \\
\text { testing and demonstration. }\end{array}$ & $\begin{array}{l}\text { No FHR has ever been built or reached detailed design level. FHRs rely } \\
\text { heavily on technologies developed for other reactor classes. Molten salt } \\
\text { hydraulic technologies were extensively investigated in the Molten Salt } \\
\text { Reactor (MSR) program that extended from the late 1940s to 1980. Notably, } \\
\text { the Molten Salt Reactor Experiment was an } 8 \text { MW MSR that operated } \\
\text { successfully from 1965-69. The performance of DRACS-type decay heat } \\
\text { removal systems was established by EBR-II testing in the 1980s. TRISO } \\
\text { fuel performance demonstration is a continuing effort of the DOE-NE } \\
\text { advanced gas reactor program. }\end{array}$ \\
\hline $\begin{array}{l}\text { Status of applicable design and } \\
\text { analysis tools. }\end{array}$ & $\begin{array}{l}\text { SmAHTR will be a thermal spectrum, LEU-fueled reactor with a single- } \\
\text { phase liquid coolant. As such, SmAHTR can rely upon established design } \\
\text { tools and methods during its pre-conceptual and conceptual design phases. } \\
\text { However, the established design tools have not been validated for use with } \\
\text { FHRs. For example, FLiBe properties have been implemented in TRACE } \\
\text { (NRC's thermal-hydraulic code package), but the resultant code predictions } \\
\text { have not been validated experimentally. Similarly, established reactor } \\
\text { physics design tools and methods (e.g., SCALE, Serpent) can be relied upon } \\
\text { to develop an initial set of reactor physics performance estimates. However, } \\
\text { reactor physics benchmark experiments will be necessary to validate the } \\
\text { code outputs before they can be used for either safety evaluation or final } \\
\text { design. }\end{array}$ \\
\hline $\begin{array}{l}\text { 5) Discussion of the assumptions } \\
\text { made regarding the expected concept } \\
\text { performance (associated with unique } \\
\text { or unproven aspects of the design) } \\
\text { and the basis of those assumptions, } \\
\text { including identification of } \\
\text { uncertainties. }\end{array}$ & $\begin{array}{l}\text { The primary assumption made in the concept performance is that laboratory- } \\
\text { scale systems can be successfully developed into industrial components in a } \\
\text { reasonable period at acceptable cost. FHRs have been under } \\
\text { evaluation/development for the past decade, and a general consensus about } \\
\text { the major elements of the reactor class has been reached. However, no firm } \\
\text { conclusions about specific technologies can yet be drawn without additional } \\
\text { development. }\end{array}$ \\
\hline $\begin{array}{l}\text { 6) Identification of major } \\
\text { technology issues, R\&D needs to } \\
\text { address design and operational } \\
\text { uncertainties, and technology gaps. }\end{array}$ & $\begin{array}{l}\text { Laying out the major FHR development issues was the subject of the } \\
\text { recently issued FHR development roadmap. SmAHTR has a large number } \\
\text { of development issues. The leading set of issues are } \\
\text { 1) tritium control, } \\
\text { 2) fuel development and qualification, } \\
\text { 3) lithium-7 cost reduction, } \\
\text { 4) licensing, } \\
\text { 5) concept maturation, } \\
\text { 6) primary coolant redox control, } \\
\text { 7) primary coolant cleanup, } \\
\text { 8) liquid salt component development and testing, } \\
\text { 9) optically-based instrumentation, } \\
\text { 10) continuous fiber composites, and } \\
\text { 11) structural alloy development and qualification. }\end{array}$ \\
\hline
\end{tabular}




\section{ATTACHMENT B-ADVANCED NUCLEAR TECHNOLOGY CRITERIA WORKSHEET Small Modular Advanced High-Temperature Reactor-Carbonate Thermochemical Cycle}

\begin{tabular}{|c|c|}
\hline Information Requested & Concept Description \\
\hline $\begin{array}{l}\text { 7) Estimated time frame and } \\
\text { required funds to develop the needed } \\
\text { information identified in Item } 6 \\
\text { above. }\end{array}$ & $\begin{array}{l}\text { The scope and duration of the required developments are sufficiently large } \\
\text { to prevent developing a realistic cost and schedule estimate. None of the } \\
\text { required technologies are anticipated to take more than a decade to develop. } \\
\text { Also, many independent actors are collaborating on early-phase technology } \\
\text { development. At least one test reactor at a minimum cost of several hundred } \\
\text { million dollars will be required along with a preceding technology } \\
\text { development program of similar scale. }\end{array}$ \\
\hline \multicolumn{2}{|l|}{ Category VI-Fuel cycle considerations } \\
\hline $\begin{array}{l}\text { 1) Ore mining and conversion } \\
\text { requirements (qualitatively } \\
\text { compared to the once-through LWR } \\
\text { cycle). }\end{array}$ & $\begin{array}{l}\text { SmAHTR employs a once-through LEU cycle with only slightly improved } \\
\text { neutronic efficiency as compared to small-sized LWRs. Consequently, } \\
\text { SmAHTR will not be significantly different from small-sized LWRs. }\end{array}$ \\
\hline $\begin{array}{l}\text { 2) Fuel fabrication (compared } \\
\text { with LWR fuel). }\end{array}$ & $\begin{array}{l}\text { Coated-particle fuel fabrication is more complex than LWR fuel pellets. At } \\
\text { the present state of the art with largely manual small-batch fabrication, } \\
\text { SmAHTR's fuel would cost substantially more than that for an LWR. While } \\
\text { identical fuel particles are applicable to FHRs and HTGRs, the cost for their } \\
\text { fuel is likely to be significantly different due to the different fuel } \\
\text { performance safety requirements of the two reactor classes. } \\
\text { FHRs have additional radionuclide containment barriers and source term } \\
\text { reduction mechanisms not available to HTGRs. The primary liquid salt coolant } \\
\text { retains all but the noble fission products. The guard vessel would maintain the } \\
\text { fuel in a cooled configuration even following vessel rupture. Liquid cooling } \\
\text { keeps the fuel at lower temperature both during normal and accident conditions, } \\
\text { promoting chemical retention of radionuclides in the fuel structures. The low } \\
\text { pressure of the primary system enables independent containment layers outside } \\
\text { of the primary coolant boundary. Consequently, FHRs are not required to rely } \\
\text { upon the fuel to achieve accident safety performance (quantitative health } \\
\text { objectives or large release frequency) goals. } \\
\text { Not relying on the fuel for accident performance significantly shifts the required } \\
\text { fuel quality assurance and, therefore, the cost. Note that high-quality fuel would } \\
\text { still be necessary, as the plant license conditions would restrict the allowable } \\
\text { amount of circulating activity to minimize worker dose. FHR fuel qualification } \\
\text { would thus be restricted to establishing that properly manufactured fuel would } \\
\text { perform adequately under normal operating conditions, and not focus on } \\
\text { demonstrating that the specific fuel in the reactor has been properly } \\
\text { manufactured or that it will perform adequately under accident conditions. In } \\
\text { practice, the lack of accident performance requirement means that FHR TRISO } \\
\text { can be manufactured to industrial quality assurance practices (ISO9000 instead } \\
\text { of NQA-1), significantly reducing the cost. }\end{array}$ \\
\hline $\begin{array}{l}\text { 3) Fuel form experience base (as } \\
\text { needed for licensing/certification) } \\
\text { for fuel forms different from current } \\
\mathrm{UO}_{2} \text { fuels (LWRs, heavy water } \\
\text { reactors (HWRs), etc.). }\end{array}$ & $\begin{array}{l}\text { Suitable coated-particle fuel for use in SmAHTR is currently being } \\
\text { demonstrated under the DOE-NE Advanced Gas Reactor (AGR) program. } \\
\text { SmAHTR, however, deploys its fuel in layered plates with the coated } \\
\text { particles located near the surface of the plates. While, conceptually, the } \\
\text { manufacturing processes of specific fuel elements do not depend on their } \\
\text { shape, plate-form TRISO fuel in liquid coolant will require testing and } \\
\text { demonstration. The plates could have failure modes that would impact the } \\
\text { core coolability, such as mechanical breakage or layer separation. } \\
\text { Demonstration of adequate fuel performance will require fabrication and } \\
\text { testing of sample fuel elements as well as qualification of their support } \\
\text { structures within the high-temperature portion of the ASME Boiler and }\end{array}$ \\
\hline
\end{tabular}




\section{ATTACHMENT B-ADVANCED NUCLEAR TECHNOLOGY CRITERIA WORKSHEET Small Modular Advanced High-Temperature Reactor-Carbonate Thermochemical Cycle}

\begin{tabular}{|c|c|}
\hline Information Requested & Concept Description \\
\hline & Pressure Vessel Code (BPVC). \\
\hline $\begin{array}{l}\text { 4) Are the systems currently used } \\
\text { for managing used fuel/ waste in } \\
\text { LWRs applicable? }\end{array}$ & $\begin{array}{l}\text { LWR used fuel storage and handling techniques would be acceptable for } \\
\text { SmAHTR. SmAHTR fuel is suitable for long-term storage in dry casks. } \\
\text { SmAHTR maintains its first level of radionuclide containment following } \\
\text { removal from the core. Also, coated-particle fuel is not water soluble, so } \\
\text { will not require the level of separation from the environment (e.g., titanium } \\
\text { drip shields) for long-term storage that is being required for LWRs. }\end{array}$ \\
\hline $\begin{array}{l}\text { 5) Is a reprocessing capability } \\
\text { required? If yes, what type of } \\
\text { technology is needed, has it been } \\
\text { proven/demonstrated, and what are } \\
\text { the waste forms? }\end{array}$ & $\begin{array}{l}\text { SmAHTR is being designed for a once-through LEU fuel cycle. SmAHTR } \\
\text { would be capable of operating on other fissile materials, but this would } \\
\text { require design modifications that are not currently intended. }\end{array}$ \\
\hline $\begin{array}{l}\text { 6) Discuss any unique } \\
\text { features/aspects of } \\
\text { processing/storage/transportation of } \\
\text { used fuel, high level waste (HLW), } \\
\text { or LLW. }\end{array}$ & $\begin{array}{l}\text { SmAHTR's fuel is not water soluble and has a lower volumetric density of } \\
\text { radionuclides that LWR fuel. SmAHTR's used fuel is well suited for direct } \\
\text { geological disposal. The long-lived, low-heat generation waste (carbon-14) } \\
\text { could also be disposed of in geologic repositories or recycled into future } \\
\text { reactors. }\end{array}$ \\
\hline \multicolumn{2}{|c|}{ Category VII-Assessment of market attractiveness } \\
\hline $\begin{array}{l}\text { 1) Energy products of the concept } \\
\text { (e.g., electricity production, } \\
\text { desalination, process heat, hydrogen } \\
\text { production) and its power (thermal, } \\
\text { electric) output and/or product } \\
\text { output. }\end{array}$ & $\begin{array}{l}\text { The primary purpose of SmAHTR-CTC is to generate hydrogen. SmAHTR- } \\
\text { CTC has a thermal power of } 125 \mathrm{MW} \text {. The minimum energy input for the } \\
\text { CTC is } 284 \mathrm{~kJ} /\left(\mathrm{g}-\mathrm{H}_{2}\right) \text {, which yields a potential production rate of } 441 \mathrm{~g} / \mathrm{s} \text {. }\end{array}$ \\
\hline $\begin{array}{l}\text { 2) Expected thermal-to-electric } \\
\text { conversion efficiency, and overall } \\
\text { multi-use plant efficiency. }\end{array}$ & $\begin{array}{l}\text { The efficiency of a thermochemical cycle is reduced from its ideal value by } \\
\text { the energy losses required to operate the processing equipment. In general, } \\
\text { higher temperatures result in higher heat losses from the plant, and higher } \\
\text { pressures require more energy for the compression and pumping. The CTC } \\
\text { is not sufficiently mature to assess the likely, industrially achieved } \\
\text { efficiency of the cycle. }\end{array}$ \\
\hline $\begin{array}{l}\text { 3) Revenue generation benefits or } \\
\text { advantages. }\end{array}$ & $\begin{array}{l}\text { The high-temperature process heat market does not have a low-carbon, on- } \\
\text { demand power source alternative to high-temperature reactors. Thus, } \\
\text { SmAHTR-CTC will not be competing against established technologies, } \\
\text { thereby easing its market introduction. A single first-of-a-kind, small plant } \\
\text { is unlikely to generate sufficient revenue from electricity sales to justify its } \\
\text { development or construction costs. Coupling coal-derived synthetic fuel } \\
\text { production with SmAHTR would markedly decrease its carbon dioxide } \\
\text { generation. The future cost of carbon dioxide releases is unknown. } \\
\text { However, if carbon dioxide emissions are taxed at a substantial rate, } \\
\text { developing and deploying small high-temperature reactors will become } \\
\text { significantly more advantageous. }\end{array}$ \\
\hline $\begin{array}{l}\text { 4) Estimated siting requirements } \\
\text { (e.g., less water usage or accident } \\
\text { consequences may favorably impact } \\
\text { siting requirements). }\end{array}$ & $\begin{array}{l}\text { SmAHTR-CTC has no evaluated accidents that result in large off-site } \\
\text { releases. Thus, the reactor's accident source term would not restrict its siting } \\
\text { locations. SmAHTR-CTC does not require either grid connection or an } \\
\text { external source of water (apart from that being split to produce hydrogen) } \\
\text { and, thus, is not site limited by resource requirements. SmAHTR's } \\
\text { components are all designed for rail or road transport. Thus, SmAHTR-CTC } \\
\text { is especially well suited for deployment in water-scarce regions at sites } \\
\text { without barge access. SmAHTR's low-pressure, below-grade construction }\end{array}$ \\
\hline
\end{tabular}




\section{ATTACHMENT B-ADVANCED NUCLEAR TECHNOLOGY CRITERIA WORKSHEET Small Modular Advanced High-Temperature Reactor-Carbonate Thermochemical Cycle}

\begin{tabular}{|c|c|}
\hline Information Requested & Concept Description \\
\hline & and passive safety characteristics increase its tolerance for seismic events. \\
\hline $\begin{array}{l}\text { 5) Environmental impacts under } \\
\text { normal/abnormal conditions, } \\
\text { including severe accident conditions, } \\
\text { and from spent fuel arrangements (as } \\
\text { compared with current LWRs). }\end{array}$ & $\begin{array}{l}\text { SmAHTR-CTC has no evaluated accidents (i.e., those with non-trivial } \\
\text { probabilities) resulting in large off-site releases. The CTC does not contain } \\
\text { highly toxic gases. SmAHTR's used fuel pool is below grade, within } \\
\text { containment, and features passive back-up decay heat removal. All fuel } \\
\text { transfers between the used fuel pool and the local, intermediate-term } \\
\text { repository will be in a passively air-cooled transfer cask. SmAHTR's } \\
\text { longer-term used fuel storage is below grade and uncooled and does not } \\
\text { have a known mechanism for environmental release of radioactivity. }\end{array}$ \\
\hline \begin{tabular}{|l|} 
6) Competitiveness on \\
international markets/export \\
potential. Specifically, what concept \\
features would make it desirable to a \\
foreign customer?
\end{tabular} & $\begin{array}{l}\text { SmAHTR-CTC will be a fully passively safe reactor system based on a LEU } \\
\text { fuel cycle. SmAHTR-CTC will be capable of being licensed in the United } \\
\text { States. SmAHTR's fuel cycle will fit with the existing IAEA safeguards } \\
\text { protocols. The plant security requirements will also be minimized by its below- } \\
\text { grade, passively safe configuration. SmAHTR's lack of requirements for } \\
\text { external power will be especially attractive to locations without a preexisting, } \\
\text { stable grid. }\end{array}$ \\
\hline $\begin{array}{l}\text { 7) Derived technologies arising } \\
\text { from concept development. }\end{array}$ & $\begin{array}{l}\text { SmAHTR-CTC's development will include a number of industrial } \\
\text { technologies. The CTC could be fed by other heat sources and thus would } \\
\text { be attractive to the coal industry independent of a reactor. SmAHTR's } \\
\text { operations and maintenance will involve higher amounts of automation and } \\
\text { remote process control than current reactors. The automation and process } \\
\text { control technologies could be widely applied outside of the nuclear power } \\
\text { arena. SmAHTR's development will also involve much greater deployment } \\
\text { of continuous fiber ceramic composites (CFCCs). The composites will have } \\
\text { widespread utility to other reactor classes and outside of nuclear power. }\end{array}$ \\
\hline $\begin{array}{l}\text { 8) Unique features affecting } \\
\text { marketability. }\end{array}$ & $\begin{array}{l}\text { SmAHTR is a high-temperature reactor, increasing its thermal efficiency for } \\
\text { electricity generation and/or enabling it to supply industrial process heat. } \\
\text { Another distinctive characteristic is SmAHTR-CTC's easily understood full } \\
\text { passive safety. No active system or operator intervention is required to } \\
\text { respond to any design basis accident. SmAHTR-CTC does not require grid } \\
\text { connection, enabling deployment in situations with isolated or unstable } \\
\text { grids. SmAHTR-CTC does not require large quantities of water-enabling } \\
\text { deployment in water-scarce regions. SmAHTR does not require barge } \\
\text { access to transport its major components, and thus can be built on lower- } \\
\text { cost land. }\end{array}$ \\
\hline $\begin{array}{l}\text { 9) Expected time frame of } \\
\text { introducing the concept to the } \\
\text { market. }\end{array}$ & 15 years with sustained RD\&D support. \\
\hline \multicolumn{2}{|l|}{ Category VIII-Economics } \\
\hline $\begin{array}{l}\text { 1) The materials and features of } \\
\text { proposed modules that would } \\
\text { improve the concept economics. }\end{array}$ & $\begin{array}{l}\text { SmAHTR features simple passive safety and does not require the multiple } \\
\text { layers of complex, expensive safety systems and structures necessary for } \\
\text { large LWRs. SmAHTR-CTC relies upon its low pressure to decrease the } \\
\text { cost of the thin-walled components and structures. Thin-walled components } \\
\text { and structures have a much larger potential supplier base that enables } \\
\text { market forces to drive down prices. As a modern design, SmAHTR can take } \\
\text { maximum advantage of reduced cost fabrication methods such as open-top } \\
\text { and modular construction. In general, the lighter, thin-walled components } \\
\text { also decrease the construction time, reducing accrued interest prior to } \\
\text { revenue generation. SmAHTR's passive safety would also both decrease the }\end{array}$ \\
\hline
\end{tabular}




\section{ATTACHMENT B-ADVANCED NUCLEAR TECHNOLOGY CRITERIA WORKSHEET Small Modular Advanced High-Temperature Reactor-Carbonate Thermochemical Cycle}

\begin{tabular}{|c|c|}
\hline Information Requested & Concept Description \\
\hline & $\begin{array}{l}\text { land acquisition cost (by enabling siting away from large water sources) and } \\
\text { significantly broaden the potential customer base. Large numbers of sales } \\
\text { will allow amortizing the development cost across a larger number of units. }\end{array}$ \\
\hline $\begin{array}{l}\text { 2) Concept improved economics } \\
\text { by design compared with LWRs } \\
\text { (e.g., length of piping, electrical } \\
\text { cables, valves, number of loops, pool } \\
\text { design). }\end{array}$ & $\begin{array}{l}\text { SmAHTR will not require the complex set of safety-related systems and } \\
\text { structures required for large LWRs. SmAHTR-CTC does not require safety- } \\
\text { grade electrical power to cool the core. None of SmAHTR's active } \\
\text { components (e.g., primary coolant pumps, control blade drive motors, } \\
\text { valves) are required to be safety grade, markedly lowering their cost. All of } \\
\text { the potential accidents evolve over many hours, which greatly simplifies the } \\
\text { communications and cabling requirements. }\end{array}$ \\
\hline 3) Cost of nuclear fuel. & $\begin{array}{l}\text { SmAHTR will rely on LEU TRISO fuel. The cost for the fuel (apart from } \\
\text { the fabrication component) will not differ substantially from that for LWRs } \\
\text { employing higher ( } 8 \mathrm{wt} \% \text { ) fuel. SmAHTR will incur substantial first-of-a- } \\
\text { kind fuel fabrication plant development costs. As a low-pressure, below- } \\
\text { grade system, with an inert coolant, SmAHTR will have multiple, } \\
\text { inexpensive containment layers. SmAHTR will, therefore, not rely on fuel } \\
\text { performance to withstand any design basis accident (e.g., avoid large offsite } \\
\text { release) or as a basis for source term minimization, which will substantially } \\
\text { reduce the fuel qualification and quality assurance requirements. Once the } \\
\text { fuel fabrication plant costs have been amortized, SmAHTR's TRISO fuel } \\
\text { fabrication costs are thus anticipated to be similar to those for LWR fuel } \\
\text { rods. }\end{array}$ \\
\hline $\begin{array}{l}\text { 4) Cost of major components. } \\
\text { Need for special materials and/or } \\
\text { construction methods (How many } \\
\text { large vessels and pipes have to be } \\
\text { fabricated, and how large would they } \\
\text { have to be?). }\end{array}$ & $\begin{array}{l}\text { SmAHTR will use thin-walled vessels and components that are markedly } \\
\text { less costly to fabricate. SmAHTR's primary alloy (likely Alloy N) was } \\
\text { patented in } 1960 \text { and hence has extensive industrial experience. Nickel- } \\
\text { based alloys have well-known fabrication methods. Fabrication of thin- } \\
\text { walled vessels, piping, and other hydraulic elements is established } \\
\text { technology. However, Alloy N is not yet an accepted material within the } \\
\text { high-temperature reactor portion of the ASME BPVC, and some additional } \\
\text { development work will thus be required for Alloy N to be used for safety } \\
\text { purposes at SmAHTR. Furthermore, CFCCs have not yet been approved for } \\
\text { use in the high-temperature reactor portion of the ASME BPVC. Until the } \\
\text { materials are approved, SmAHTR cannot be licensed in the United States. } \\
\text { The CFCC components will also be somewhat larger than anticipated in } \\
\text { other industrial deployments. Thus, SmAHTR will incur additional one-time } \\
\text { costs to scale up the fabrication equipment necessary for its CFCCs } \\
\text { (principally vacuum furnaces). } \\
\text { SmAHTR is dependent on an industrial-scale supply of isotopically } \\
\text { separated }{ }^{7} \text { Li. Industrial-scale production of }{ }^{7} \text { Li at acceptable cost was } \\
\text { accomplished in the } 1950 \text { s. However, the technique used is no longer } \\
\text { environmentally acceptable. Several techniques appear to both offer } \\
\text { improved performance relative to the older technology as well as being } \\
\text { environmentally acceptable. However, }{ }^{7} \text { Li production technology will need } \\
\text { to be developed and scaled to industrial size for SmAHTR to be viable. }\end{array}$ \\
\hline $\begin{array}{l}\text { 5) Estimated construction schedule } \\
\text { (as compared with LWRs). }\end{array}$ & $\begin{array}{l}\text { SmAHTR's design is not sufficiently advanced to develop a specific } \\
\text { construction schedule. Similar to other advanced SMRs, SmAHTR-CTC is } \\
\text { based upon site assembly of pre-fabricated modules; thus, much of the } \\
\text { construction and assembly schedule will be similar to that of other advanced } \\
\text { SMRs. The most notable difference in SmAHTR-CTC's construction } \\
\text { schedule would be the time-savings due to the lack of requirement for a }\end{array}$ \\
\hline
\end{tabular}




\section{ATTACHMENT B-ADVANCED NUCLEAR TECHNOLOGY CRITERIA WORKSHEET Small Modular Advanced High-Temperature Reactor-Carbonate Thermochemical Cycle}

\begin{tabular}{|c|c|}
\hline Information Requested & Concept Description \\
\hline & massive containment. \\
\hline $\begin{array}{l}\text { 6) Need for special skill sets and/or } \\
\text { procedures required for construction } \\
\text { (and their availability) and } \\
\text { operations (and their availability). }\end{array}$ & $\begin{array}{l}\text { SmAHTR can be fabricated using standard industrial construction skills. } \\
\text { While the skills for handling molten fluoride salts are less common, molten } \\
\text { fluoride salts are commonly used in aluminum oxide reduction. } \\
\text { Consequently, extensive industrial experience exists on heating and } \\
\text { transferring the salts. Note that all FHRs will require higher salt purity } \\
\text { (lower water contamination) than is currently industrial practice. Salt } \\
\text { preparation and handling will require specialized skills to acquire adequate } \\
\text { material purity. }\end{array}$ \\
\hline 7) Estimated overnight capital cost. & $\begin{array}{l}\text { SmAHTR-CTC's design is not sufficiently mature to provide a reasonable } \\
\text { cost estimate. }\end{array}$ \\
\hline $\begin{array}{l}\text { 8) Estimated yearly operational } \\
\text { cost (accounting for } \\
\text { decommissioning and waste } \\
\text { management). }\end{array}$ & $\begin{array}{l}\text { SmAHTR-CTC's design is not sufficiently mature to provide a reasonable } \\
\text { cost estimate. }\end{array}$ \\
\hline 9) Estimated cost of electricity. & SmAHTR-CTC is not intended as an electricity supplier. \\
\hline \multicolumn{2}{|c|}{ Category IX-Potential regulatory licensing environment } \\
\hline $\begin{array}{l}\text { 1) A description of the licensing } \\
\text { approach envisioned for the } \\
\text { proposed concept. This would } \\
\text { include the general applicability of } \\
\text { current regulatory requirements (10 } \\
\text { Code of Federal Regulations (CFR) } \\
50,52) \text { and guidance documents } \\
\text { (e.g., NUREG-0800 and Regulatory } \\
\text { Guides) to concept design, } \\
\text { construction, and operating } \\
\text { licensing. }\end{array}$ & $\begin{array}{l}\text { SmAHTR-CTC is suitable for licensing under a deterministic licensing } \\
\text { framework similar to 10CFR50 or } 52 \text {. The technology-neutral general } \\
\text { design criteria (GDCs) that are currently under development under a joint } \\
\text { initiative by DOE and the NRC will be used as the starting point for } \\
\text { SmAHTR-CTC licensing. The ANS FHR design safety standard will be } \\
\text { relied upon to provide class-specific GDCs derived from the technology- } \\
\text { neutral set. An FHR class-specific review standard (with a limited set of } \\
\text { SmAHTR specific modifications) similar to NUREG-0800 will be necessary } \\
\text { to provide guidance to both the design team and NRC staff on how to } \\
\text { evaluate whether the design as met the criteria. } \\
\text { A SmAHTR-CTC specific master logic diagram will provide the starting } \\
\text { point for determining initiating events and design basis accidents. The } \\
\text { performance requirements for the design basis accidents will determine the } \\
\text { safety classification for SmAHTR's SSCs. As no FHR has ever been built, } \\
\text { only rudimentary probabilistic analysis is yet available. The probabilistic } \\
\text { analysis will be used along with the accident progression evaluation to } \\
\text { facilitate graceful plant degradation for beyond design basis events. }\end{array}$ \\
\hline $\begin{array}{l}\text { 2) Concept design/operational } \\
\text { features that may positively impact } \\
\text { licensing requirements (e.g., } \\
\text { enhanced passive safety, low- } \\
\text { pressure operation). }\end{array}$ & $\begin{array}{l}\text { SmAHTR has substantial margin to primary coolant boiling and/or fuel } \\
\text { damage }(\sim 700 \mathrm{~K}) \text {. SmAHTR has multiple, independent radionuclide } \\
\text { containment layers along with significant source term reduction } \\
\text { mechanisms. The fuel body and primary coolant combine to chemically and } \\
\text { physically retain all but the noble fission gasses. Even in the event of a } \\
\text { beyond design basis event such as a vessel rupture, SmAHTR's guard vessel } \\
\text { will prevent uncovering the core and decay heat removal system. } \\
\text { SmAHTR's low pressure both significantly reduces the cost of containment } \\
\text { layers and prevents developing a driving force for dispersing radionuclides. } \\
\text { SmAHTR's single-phase, transparent coolant enables direct observation of } \\
\text { the core condition and coolability, providing high confidence that a severe } \\
\text { fuel damage event is accident is not imminent. }\end{array}$ \\
\hline $\begin{array}{l}\text { 3) Concept } \\
\text { design/technology/operational } \\
\text { features that have not been subject }\end{array}$ & $\begin{array}{l}\text { FHRs are a new reactor class. Many of their features differ markedly from } \\
\text { LWRs and thus have not been licensed. The FHR technology development } \\
\text { roadmap (ORNL/TM-2013/401) documents of the feature differences. Some }\end{array}$ \\
\hline
\end{tabular}




\section{ATTACHMENT B-ADVANCED NUCLEAR TECHNOLOGY CRITERIA WORKSHEET Small Modular Advanced High-Temperature Reactor-Carbonate Thermochemical Cycle}

\begin{tabular}{|c|c|}
\hline Information Requested & Concept Description \\
\hline $\begin{array}{l}\text { to the licensing process for the } \\
\text { current fleet of LWRs. }\end{array}$ & $\begin{array}{l}\text { of the most prominent issues that remain to be addressed in the licensing } \\
\text { process are } \\
\text { 1) structural alloy qualification, } \\
\text { 2) structural ceramic qualification, } \\
\text { 3) TRISO fuel qualification, } \\
\text { 4) layered TRISO fuel structure qualification, } \\
\text { 5) DRACS decay heat removal, } \\
\text { 6) liquid salt hydraulic code qualification, } \\
\text { 7) reactor physics modeling qualification, } \\
\text { 8) tritium capture and control technology, and } \\
\text { 9) alternate measurement technologies and communications } \\
\end{array}$ \\
\hline $\begin{array}{l}\text { 4) Applicability of current codes } \\
\text { and standards and possible } \\
\text { development required. }\end{array}$ & $\begin{array}{l}\text { FHRs will require modifications to the existing set of codes and standards } \\
\text { for NPP design and licensing, but will not require wholesale differences } \\
\text { from current practice. For example, both ASTM and ASME are currently } \\
\text { developing code rules for CFCCs for nuclear power plant use due to the } \\
\text { general applicability of the technology (e.g., BWRs are evaluating SiC/SiC } \\
\text { composites for channel boxes to minimize the amount of zirconium in core). } \\
\text { Hastelloy® N (trade name for Alloy N) currently has a partial code case for } \\
\text { high-temperature reactor use based upon the earlier MSR program. While } \\
\text { additional data will be required to develop a modern code case, FHRs can } \\
\text { rely upon the extensive set of data that has already been developed. }\end{array}$ \\
\hline $\begin{array}{l}\text { 5) Applicability of current analysis } \\
\text { tools and data. }\end{array}$ & $\begin{array}{l}\text { SmAHTR is a thermal spectrum, uranium-fueled reactor concept using } \\
\text { single-phase liquid cooling. Existing reactor physics and thermal-hydraulics } \\
\text { tools will thus be generally applicable to SmAHTR, but will require } \\
\text { experimental validation before being able to be used for safety evaluation. } \\
\text { The NRC thermal and hydraulic code TRACE already has fluoride salt } \\
\text { properties implemented within it. However, the code performance with the } \\
\text { salt properties has not yet been experimentally validated. Similarly, key } \\
\text { reactor physics codes such as SCALE, MCNP, and Serpent have been used } \\
\text { for FHR evaluation and provide generally consistent results. However, } \\
\text { reactor physics code benchmarking experiments will be required before any } \\
\text { can be used in a licensing action. }\end{array}$ \\
\hline $\begin{array}{l}\text { 6) Knowledge base and skills of } \\
\text { NRC staff to address concept design } \\
\text { and licensing. }\end{array}$ & $\begin{array}{l}\text { The NRC has a limited existing skill set to address the specific design issues } \\
\text { for SmAHTR. However, the general simplicity of the plant nuclear safety is } \\
\text { a principal design virtue of FHRs, reducing the required staff training to } \\
\text { develop FHR licensing capabilities. }\end{array}$ \\
\hline $\begin{array}{l}\text { 7) Estimated validation and } \\
\text { verification effort (tests and } \\
\text { computer codes). }\end{array}$ & $\begin{array}{l}\text { Thermal, hydraulic, and reactor physics code validation will be required. } \\
\text { Liquid fluoride salts at operating temperature have heat transfer } \\
\text { performance similar to those of lower-temperature simulant fluids, reducing } \\
\text { the required experimental code validation effort. }\end{array}$ \\
\hline $\begin{array}{l}\text { 8) Identification of any additional } \\
\text { regulatory activities or products, } \\
\text { such as previous NRC reviews or } \\
\text { research efforts that could enhance } \\
\text { the licensing ability of the concept. }\end{array}$ & $\begin{array}{l}\text { The primary regulatory efforts supporting FHRs are the current joint DOE- } \\
\text { NE and NRC initiative to develop technology-neutral GDC for advanced } \\
\text { nuclear power plants and NRC Office of New Reactor Regulation } \\
\text { participation in ANS } 20.1 \text { FHR design safety standard development. }\end{array}$ \\
\hline $\begin{array}{l}\text { 9) The effect of unique fuel } \\
\text { configurations on the licensing } \\
\text { requirements for storage of spent }\end{array}$ & $\begin{array}{l}\text { Used TRISO fuel is substantially more robust than used LWR fuel. The SiC } \\
\text { containment layer remains with the fuel. The fuel coating is not water } \\
\text { soluble, avoiding the principal radionuclide transport mechanism applicable }\end{array}$ \\
\hline
\end{tabular}




\section{ATTACHMENT B-ADVANCED NUCLEAR TECHNOLOGY CRITERIA WORKSHEET Small Modular Advanced High-Temperature Reactor-Carbonate Thermochemical Cycle}

\begin{tabular}{|l|}
\hline Information Requested \\
\hline nuclear fuel. In addition to the \\
relevant regulatory requirements in \\
10 CFR Parts 20,50, and 52, the \\
participant should address any \\
unique issues of how the \\
requirements of 10 CFR Part 72 \\
would impact long-term storage of \\
spent nuclear fuel.
\end{tabular}

\section{Category X-Nonproliferation}

1) Characteristics of the fresh and spent/used fuel.
Concept Description

to used LWR fuel. SmAHTR's fuel assemblies are suitable for direct, indefinite term, local, below-grade storage. SmAHTR's fuel assemblies will have significantly lower volumetric decay heat than LWR fuel assemblies due to the lower uranium loading. However, SmAHTR will generate a substantially larger volume of used fuel assemblies $\left(4.5 \mathrm{~m}^{3} /\right.$ year $)$ than LWRs due to the lower fuel loading. Of this volume, $16 \%$ is the empty space between the fuel plates. Over $90 \%$ of the solid-occupied volume is (low-level) activated carbon.

\begin{tabular}{|c|c|}
\hline & $\begin{array}{l}\text { and has an apothem of } 22.5 \text { centimeters. Each fuel assembly contains } 18 \\
\text { fuel plates that are } 2.55 \mathrm{~cm} \times 22.5 \mathrm{~cm} \times 450 \mathrm{~cm} \text {. The fissile material is } \\
8 \mathrm{wt} \% \text { enriched uranium and is in the form of TRISO fuel particles } \\
\text { embedded within the fuel plates. Each fuel plate will contain about } 5.5 \mathrm{~kg} \\
\text { of uranium, resulting in a total fuel mass of } 1,877 \mathrm{~kg} \text { of uranium in the fresh } \\
\text { core. Used SmAHTR fuel will have similar isotopic composition and } \\
\text { radionuclide characteristics to those of used LWR fuel. }\end{array}$ \\
\hline $\begin{array}{l}\text { 2) Other design characteristics that } \\
\text { impact the materials control and } \\
\text { accounting system (and whether } \\
\text { significant development of a } \\
\text { materials control and accounting } \\
\text { methodology will be needed). }\end{array}$ & $\begin{array}{l}\text { SmAHTR's fuel accounting system will be similar to that employed in } \\
\text { PWRs (i.e., looking as the serial numbers engraved on individual fuel } \\
\text { elements). Fuel in the used fuel pool can be visually observed. As with } \\
\text { LWR fuel assemblies, monitoring the isotopic content of interior fuel } \\
\text { elements will be difficult due to the masking effect of large signals provided } \\
\text { by the exterior elements. } \\
\text { Below-grade intermediate-term storage provides an advantageous geometry } \\
\text { for monitoring individual fuel assemblies using conventional technology. } \\
\text { Drilling a monitoring well adjacent to the storage well will allow fuel } \\
\text { radiation and thermal signatures of each fuel assembly to be continuously } \\
\text { monitored during storage. } \\
\text { The mechanical and chemical robustness of the fuel particles also enhances } \\
\text { the material control. Large-scale fuel reprocessing would require } \\
\text { development of fuel grinding technology that remains undemonstrated under } \\
\text { relevant conditions. }\end{array}$ \\
\hline $\begin{array}{l}\text { 3) Operational concept for the } \\
\text { design as may impact proliferation } \\
\text { risk. }\end{array}$ & $\begin{array}{l}\text { In most aspects, the operational concepts for FHRs as they relate to } \\
\text { proliferation risk will be similar to those for LWRs. The fuel is comprised of } \\
\text { large assemblies with LEU as its fissile material. Diversion of used fuel is } \\
\text { prevented largely by the difficulty of working with highly radioactive } \\
\text { materials. SmAHTR-CTC is planning to employ significantly more vision- } \\
\text { based instrumentation both in-vessel and in-containment than has been } \\
\text { commonplace with LWRs. Continuous video surveillance of the fuel would } \\
\text { increase confidence that fuel is not being diverted. }\end{array}$ \\
\hline $\begin{array}{l}\text { 4) Relevant integral } \\
\text { nonproliferation and security } \\
\text { perspectives (e.g., material } \\
\text { attractiveness of fuel considered in } \\
\text { the context of anticipated security } \\
\text { features/operational concept). }\end{array}$ & $\begin{array}{l}\text { The integral nonproliferation and security risks of SmAHTR will be similar } \\
\text { to those of LWRs. SmAHTR's nuclear island is largely underground behind } \\
\text { multiple layers of robust defenses. Used fuel will be highly radioactive and } \\
\text { thus self-guarding. Fresh fuel will be composed of large structures } \\
\text { containing low enrichment uranium. Transferring used fuel from the used } \\
\text { fuel pool to the storage site will entail a shielded, bottom-loading cask } \\
\text { moved by heavy lift machinery. }\end{array}$ \\
\hline
\end{tabular}




\section{ATTACHMENT B-ADVANCED NUCLEAR TECHNOLOGY CRITERIA WORKSHEET Small Modular Advanced High-Temperature Reactor-Carbonate Thermochemical Cycle}

\begin{tabular}{|c|c|}
\hline Information Requested & Concept Description \\
\hline \multicolumn{2}{|c|}{ Category XI-Research and development needs } \\
\hline $\begin{array}{l}\text { 1) A description of the key } R \& D \\
\text { needs that could be reasonably } \\
\text { supported by a national laboratory. }\end{array}$ & $\begin{array}{l}\text { FHRs are emerging from concept validation studies and entering into early } \\
\text { phase engineering development. National laboratories would be the } \\
\text { preferred location for the next phase of RD\&D. The recent FHR technology } \\
\text { development roadmap (ORNL/TM-2013/401) provides an overview of the } \\
\text { set of development activities. Key efforts include material development and } \\
\text { testing, thermal and hydraulic experiments, component development and } \\
\text { testing, concept development, instrumentation development and testing, } \\
\text { concept of operations planning, fuel testing, safety analysis, salt technology } \\
\text { demonstration, and lithium isotope separation technology development. }\end{array}$ \\
\hline $\begin{array}{l}\text { 2) Identification of the general } \\
\text { costs for the identified R\&D. }\end{array}$ & $\begin{array}{l}\text { FHRs have substantial remaining development costs, notably including at } \\
\text { least one test reactor. China is currently planning on constructing two FHR } \\
\text { test reactors in sequence. If the United States has access to the data } \\
\text { developed by the Chinese program, US FHR development costs will be } \\
\text { substantially reduced. Nevertheless, US FHR development costs will be in } \\
\text { excess of } \$ 100 \mathrm{M} \text {. Without access to the Chinese program, the development } \\
\text { costs will be in the } \$ 1-2 \mathrm{~B} \text { range because of the need to design and build a } \\
\text { test reactor. }\end{array}$ \\
\hline $\begin{array}{l}\text { 3) Identification of the time frame } \\
\text { in which the R\&D is needed. }\end{array}$ & $\begin{array}{l}\text { No technologies requiring more than a decade of development effort have } \\
\text { been identified for SmAHTR. The Chinese program is progressing rapidly } \\
\text { with two test reactors planned prior to } 2025 \text {. Thus, the US effort should be } \\
\text { focused on complementary developments over the next decade. }\end{array}$ \\
\hline $\begin{array}{l}\text { 4) Relative prioritization of } \\
\text { potential } R \& D \text { activities. }\end{array}$ & $\begin{array}{l}\text { While the full set of FHR technology development issues described in the } \\
\text { FHR development roadmap (ORNL/TM-2013/401) will eventually need to } \\
\text { be addressed, the set of technology development issues recommended as the } \\
\text { initial focus of a broadly based development program are tritium control, } \\
\text { fuel development and qualification, lithium-7 separation cost reduction, } \\
\text { licensing framework development, concept maturation (including the CTC), } \\
\text { primary coolant redox control, primary coolant cleanup, liquid salt test loop } \\
\text { experimentation, optically based instrumentation development, continuous } \\
\text { fiber ceramic composite testing and qualification, structural alloy testing and } \\
\text { qualification, and surrogate material thermal and hydraulic testing. }\end{array}$ \\
\hline
\end{tabular}

